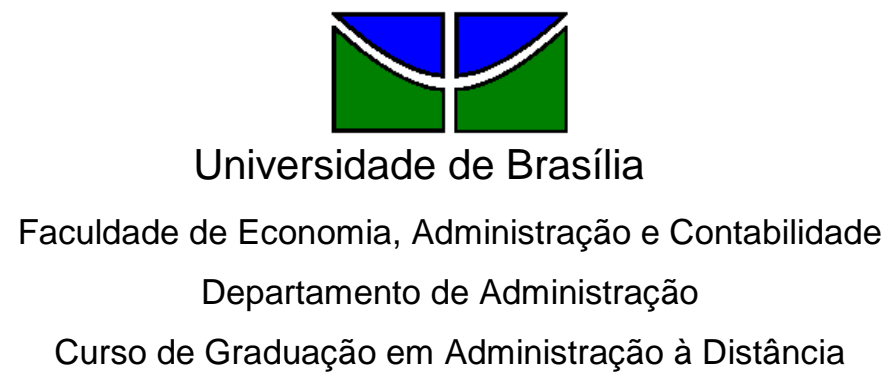

MARCELO TOBIAS SOUZA

\title{
SISTEMA DE REGISTRO DE PREÇOS: a celeridade nas contratações de bens e serviços através da adesão à Ata de Registro de Preços
}

Brasília - DF 


\section{MARCELO TOBIAS SOUZA}

\section{SISTEMA DE REGISTRO DE PREÇOS: a celeridade nas contratações de bens e serviços através da adesão à Ata de Registro de Preços}

Monografia apresentada à Universidade de Brasília (UnB) como requisito parcial para obtenção do grau de Bacharel em Administração.

Professora Orientadora: Me. Maria Neuza da Silva Oliveira

$$
\text { Brasília - DF }
$$


Souza, Marcelo Tobias

Sistema de Registro de Preços: a celeridade nas contratações de bens e serviços através da adesão à Ata Registro de Preços. - Brasília, 2011.

$59 \mathrm{fls}$.

Monografia (bacharelado) - Universidade de Brasília, Departamento de Administração - EaD, 2011.

Orientador: Profạ. Maria Neuza da Silva Oliveira, Departamento de Administração.

1. Licitações. 2. Contratações Públicas. 3. Ata de Registro de Preços. 


\title{
MARCELO TOBIAS SOUZA
}

\section{SISTEMA DE REGISTRO DE PREÇOS: a celeridade nas contratações de bens e serviços através da adesão à Ata de Registro de Preços}

A Comissão Examinadora, abaixo identificada, aprova o Trabalho de Conclusão do Curso de Administração da Universidade de Brasília do aluno

\author{
Marcelo Tobias Souza \\ Titulação, Maria Neuza da Silva Oliveira, \\ Professora-Orientadora \\ Professor, José Matias-Pereira \\ Professor-Examinador
}

Brasília, 03 de dezembro de 2011. 


\section{AGRADECIMENTOS}

A minha professora, Maria Neuza da Silva Oliveira por toda sua atenção, sabedoria, paciência e apoio.

Aos colegas: Jocelan Luiz dos Santos, Michelle Alves Marques, Ligia Pereira de Sousa, Luis Aberto de Sousa Santos, José Eguimar Soares Filho, Célia Maxiqueira Soares, Bruno Maxiqueira Soares, José Carlos do Amaral e Mario Sergio Xavier Regattieri, que colaboraram com as informações necessárias a este estudo e pelo companheirismo incondicional, compreensão e ajuda em cada parte desta Monografia.

Aos meus familiares, em especial minha querida mãe lolanda Tobias Souza, meu pai Samuel Silva Souza e minha querida irmã pelo amor e por tudo que me ensinou como exemplo de vida.

A minha esposa Simone Camargo de Lima Souza, minha filha Juliana Regina Camargo de Lima Souza, pelo apoio que me deram para que não desistisse no meio do caminho e terem acreditado no meu potencial. 


\section{RESUMO}

Este trabalho visa abordar a prática da adesão da Ata de Registro de Preços por órgãos não participantes da licitação pelo Sistema de Registro de Preços promovido por outro órgão, procedimento que vem sendo chamado de carona. Dessa maneira, o propósito deste trabalho foi verificar porque o Ministério da Defesa não tinha como prática a adoção de Ata de Registro de preços prevista no Decreto 3.931, de 19 de setembro de 2001. A pesquisa desenvolvida foi qualitativa e para atingir seus objetivos foram realizadas pesquisas bibliográficas e de campo. Com base nos resultados obtidos a partir das entrevistas, foi possível constatar que existem dois entendimentos em relação à adesão a Ata de Registro de Preços, um por parte dos gestores e outra por parte dos profissionais de direito.

1. Licitações. 2. Contratações Públicas. 3. Ata de Registro de Preços 


\section{SUMÁRIO}

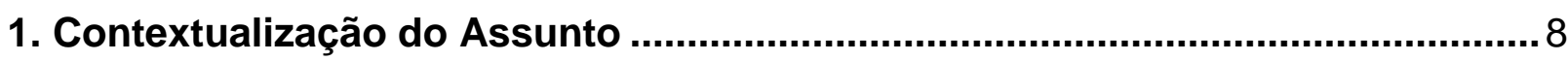

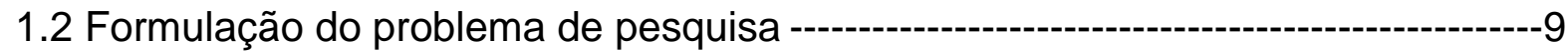

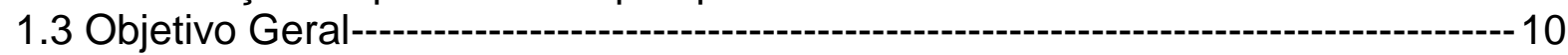

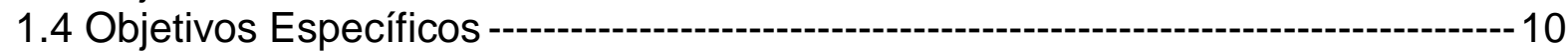

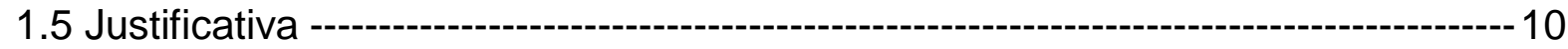

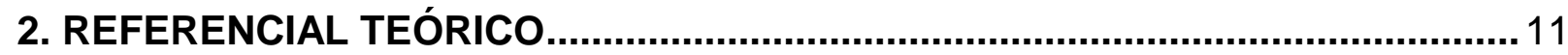

2.1 Princípios Básicos que Regem o Procedimento Administrativo--------------- 17

2.1.2 Modalidades de Licitação ---

2.2. Sistema de Registro de Preços --

2.2.1. Registro de Preços ---or

2.2.2 Órgão Gerenciador, Participante e Carona ----------------------------27

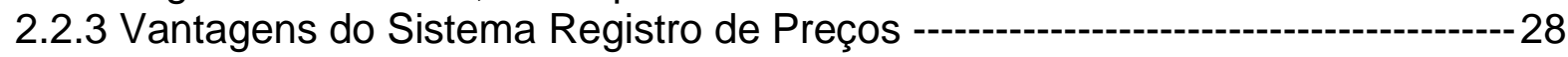

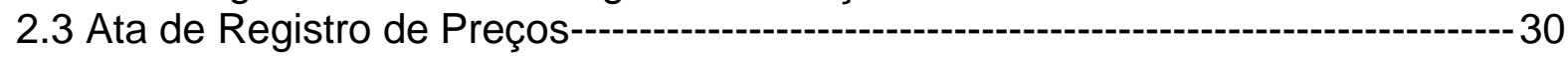

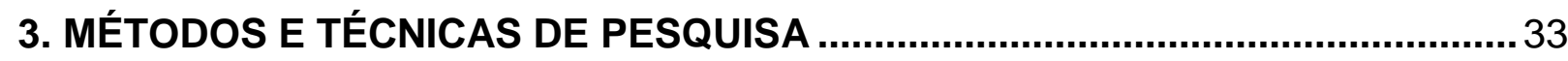

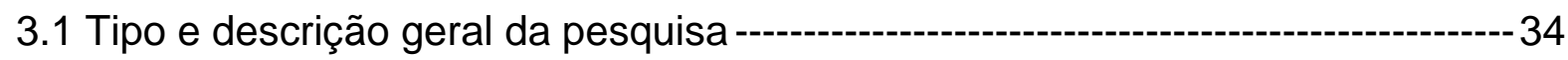

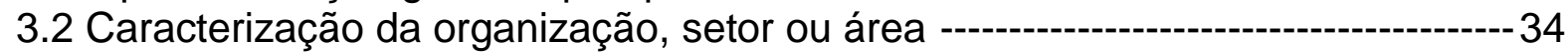

3.3 População e Amostra ou Participantes do Estudo --------------------------36

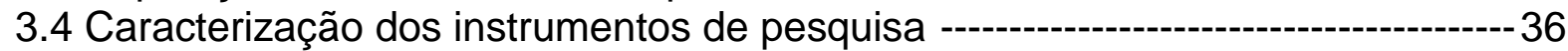

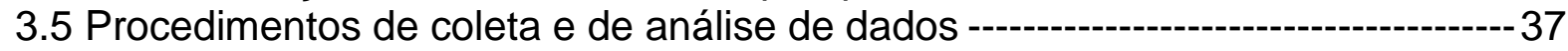

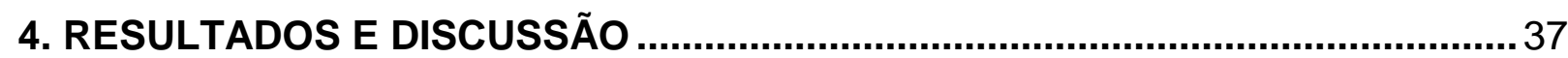

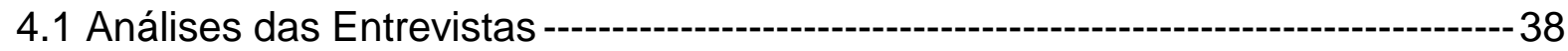

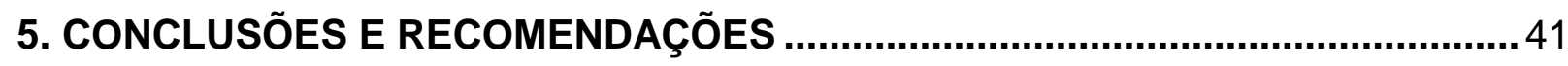

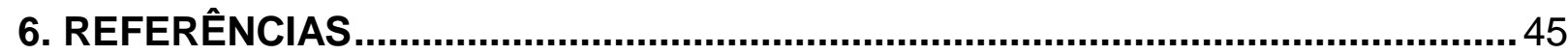

Apêndice "A" Roteiro da entrevista semi-estruturada ..........................................4 48

ANEXO "A" Quadro das quantidades de licitações realizadas em 2010, conforme portal do comprasnet. ............................... Erro! Indicador não definido.

ANEXO “B" Decreto $n^{\circ}$ 3.931, de 19 de setembro de 2001..................................51 


\section{Contextualização do Assunto}

A gestão de compras adota atualmente tem um papel estratégico dentro das instituições. De acordo com Nunes \& Lucena (2007), para qualquer organização, o setor de compras deve se constituir como um dos segmentos principais para o alcance dos objetivos estratégicos organizacionais.

Para Nunes \& Lucena (2007), o sistema de compras apresenta algumas diferenças quando se compara o setor público às empresas privadas. Ao contrário das empresas privadas, que têm ampla liberdade de escolha nas decisões sobre suas aquisições e necessitam de um setor de compras eficiente para minimizar seus custos e maximizar seus lucros.

As organizações públicas buscam o interesse comum, e somente podem fazer aquilo que a lei estabelece, por isso necessitam de uma gestão de compras eficiente para garantir a transparência nas relações e a eficácia na alocação dos recursos para satisfazer a sociedade.

A Constituição Federal do Brasil de 1988, com o intuito de regulamentar as compras públicas, em seu artigo 37 , inciso XXI, estabeleceu que a administração pública direta e indireta de qualquer dos poderes da União, Estados, Distrito Federal e Municípios deve adquirir bens e serviços mediante processo de licitação pública que assegure igualdade de condições a todos os concorrentes (BRASIL, 1988).

A contratação de bens ou serviços por meio do Sistema de Registro de Preços encontra-se prevista no art. 15 da Lei no 8.666, (BRASIL, 1993). O referido artigo foi regulamentado pelo Decreto № 3.931, (BRASIL, 2001), que, em seu art. $8^{\circ}$, prevê a possibilidade de órgãos ou entidades da Administração que não tenham participado do certame licitatório utilizarem-se da Ata de Registro de Preços elaborada por órgão da Administração Pública Federal.

Acertadamente, o Decreto $\mathrm{n}^{-}$3.931, (BRASIL 2001), estendeu a possibilidade de utilização da Ata de Registro de Preços àqueles órgãos e entidades da Administração Pública que não tenha participado do Sistema de Registro de Preço, (SRP). 
Segundo Fernandes, (2006, p.208), "órgãos não participantes (caronas) são aqueles que não tendo participado na época oportuna, informando suas estimativas de consumo, requerem, posteriormente, ao órgão gerenciador, o uso da Ata de Registro de Preços".

Com Regulamentação do Sistema de Registro de Preços previsto no art. 15 da Lei no 8.666, (BRASIL, 1993), através Decreto 3.931 (BRASIL, 2001), grande parte da Administração Pública Federal utiliza o Sistema no processo de contratações de bens e serviços. O diagnóstico de contratações públicas através do Sistema Registro de Preços motivou o problema dessa pesquisa.

Neste contexto, este trabalho visou explorar os conceitos de celeridade nas contratações públicas na Administração Pública. A partir de um estudo realizado no Ministério da Defesa (MD), buscou-se identificar as restrições nas contratações no sentido de não adotar como prática a adesão a Ata Registro de Preços de outros Órgãos, ouvindo a opinião dos responsáveis pelas compras do órgão. $O$ intuito é oferecer aos gestores um espectro geral do Sistema Registro de Preços, e em particular a vantagem do Órgão não participante em aderir uma Ata Registro de Preços, com isso, objetiva-se fornecer dados que poderão contribuir para o aprimoramento da gestão de compras na Administração do Ministério da Defesa.

\subsection{Formulação do problema de pesquisa}

Na prática, órgão não participante que é o carona, ou seja, aquele que não tendo participado na época oportuna da licitação, informa suas estimativas de consumo e requerem ao órgão gerenciador o uso da Ata de Registro de Preços. E essa prática é consideradamente uma vantagem, pois, se reduz o prazo processual, se economiza em diversos aspectos referentes às fases interna e externa da licitação, se possibilita o atendimento de demandas imprevisíveis, além de outras vantagens. Como o Decreto o 3.931, (BRASIL, 2001), não estabeleceu regras claras acerca de tal adesão, muito se tem realizado sem a formalização devida.

Embora o Decreto o 3.931, (BRASIL, 2001), no seu art 8o, prevê a utilização da ferramenta de adesão a Ata de Registro de Preços no âmbito da Administração Federal direta, autárquica e fundacional, fundos especiais, empresas públicas, sociedades de economia mista e demais entidades 
controladas, direta ou indiretamente pela União, com a finalidade de dar mais eficiência e agilidades nas aquisições. No entanto por que o Ministério da Defesa não utiliza esta ferramenta como prática ordinária?

\subsection{Objetivo Geral}

Analisar as vantagens da adesão à Ata de Registro de Preços como instrumento e ferramenta administrativa nas contratações Públicas.

\subsection{Objetivos Específicos}

- Analisar o processo de contratações de bens e serviços do Ministério da Defesa (MD);

- Identificar as vantagens encontradas por órgão não participante nas contratações de bens e serviços na Administração Pública; e

- Mostrar as vantagens do Sistema Registro de Preços nas contratações Públicas.

\subsection{Justificativa}

Exercer uma administração eficiente e eficaz é um desafio para todo Gestor em qualquer segmento, estejam estes à frente de empresas, públicas ou privadas, cooperativas, organizações não governamentais (ONG), fundações, autarquias ou da própria Administração Direta do Governo, que foi foco da pesquisa realizada.

No que tange à Administração Pública, a tarefa é ainda mais complexa, uma vez que a Gestão adotada deve atender às necessidades da instituição não só de forma eficiente e eficaz, mais levando em conta o princípio da economicidade, pois se utiliza o dinheiro público, na ocasião da realização das contratações públicas.

A realização do processo licitatório ocorre de forma burocrática e demorada. Burocrática pelo fato de a tramitação do processo necessitar atender a todos os prazos legais previstos nas legislações que o regulamenta; demorada em decorrência de tal burocracia.

Os fundamentos para a realização deste trabalho são no sentido de contribuir de forma a mostrar que as aquisições de bens e serviços podem ser mais céleres e com mais efetividade sem contrariar as legislações e os ordenamentos jurídicos que tratam do tema licitação e contratos. 


\title{
2. REFERENCIAL TEÓRICO
}

Inicialmente, é importante apresentar o significado do que é licitação para que se tenha um entendimento mais acurado do estudo, conforme se pode verificar segundo Mukai:

\begin{abstract}
A licitação significa um cotejo de ofertas (propostas), feita por particulares ao Poder Público, visando a execução de uma obra, a prestação de um serviço, um fornecimento ou mesmo ou mesmo alienação pela administração, donde se há de escolher aquela (proposta) que maior vantagem oferecer, mediante um processo administrativo regrado, que proporcione tratamento igualitário aos proponentes, findo o qual poderá ser contratado aquele que tiver oferecido a melhor proposta.(MUKAl, 1999, p. 1).
\end{abstract}

Como o estudo em questão se refere mais especificamente à legislação que trata do instituto da licitação, também se faz relevante tratar um pouco do histórico legal, do momento do aparecimento desse instituto, conforme se refere Barbosa:

\begin{abstract}
O Instituto da Licitação está configurado no direito público brasileiro desde o século XIX. O primeiro diploma legal a tratar do assunto foi o Decreto $\mathrm{n}^{\circ}$ 2.926, de 14 de maio de 1862, que regulava as arrematações e serviços a cargo do Ministério da Agricultura, Comércio e Obras Públicas. (BARBOSA, 2008, p. 11).
\end{abstract}

Além de o instituto da licitação estar previsto conforme mencionado por Barbosa (2008, p. 11), também cita a previsão na Lei Orçamentária ํo 2.221 (BRASIL, 1909), que fixou regras a serem observadas nos processos das concorrências, mais especificamente que fixou a despesa geral do Brasil para o exercício de 1912.

Outras legislações também contemplaram tal instituto, mas o estudo em questão se atém à legislação em vigor, como é o caso da Constituição Federal (BRASIL. Constituição, 1988), que faz quatro referências, dispondo nos seus artigos. 22, 24, 37 e 173 que:

Art. 22. Compete privativamente à União legislar sobre:

(...)

XXVII - normas gerais de licitação e contratação, em todas as modalidades, para as administrações públicas diretas, autárquicas e fundacionais da União, Estados, Distrito Federal e Municípios, obedecido o disposto no art. 37, XXI, e para as empresas públicas e sociedades de economia mista, nos termos do art. 173, $\S 1^{\circ}$, III; (Redação dada pela Emenda Constitucional no 19, de 1998)

Art. 24. Compete à União, aos Estados e ao Distrito Federal legislar concorrentemente sobre:

I - direito tributário, financeiro, penitenciário, econômico e urbanístico; 
$\S 1^{0}$ - No âmbito da legislação concorrente, a competência da União limitar-se-á a estabelecer normas gerais.

Art. 37. A administração pública direta e indireta de qualquer dos Poderes da União, dos Estados, do Distrito Federal e dos Municípios obedecerá aos princípios de legalidade, impessoalidade, moralidade, publicidade e eficiência e, também, ao seguinte:

$(\ldots)$

$X X I$ - ressalvados os casos especificados na legislação, as obras, serviços, compras e alienações serão contratados mediante processo de licitação pública que assegure igualdade de condições a todos os concorrentes, com cláusulas que estabeleçam obrigações de pagamento, mantidas as condições efetivas da proposta, nos termos da lei, o qual somente permitirá as exigências de qualificação técnica e econômica indispensáveis à garantia do cumprimento das obrigações.

Art. 173. Ressalvados os casos previstos nesta Constituição, a exploração direta de atividade econômica pelo Estado só será permitida quando necessária aos imperativos da segurança nacional ou a relevante interesse coletivo, conforme definidos em lei.

$\S 1$ 1 A lei estabelecerá o estatuto jurídico da empresa pública, da sociedade de economia mista e de suas subsidiárias que explorem atividade econômica de produção ou comercialização de bens ou de prestação de serviços, dispondo sobre:

(...)

III - licitação e contratação de obras, serviços, compras e alienações, observados os princípios da administração pública;

Quanto ao art. 173, posteriormente, ocorreram algumas alterações, conforme se pode verificar na Emenda Constitucional nำ19, (BRASIL, 1988), que passa a vigorar com a seguinte redação:

Art.173

$\S 1^{\circ}$ A lei estabelecerá o estatuto jurídico da empresa pública, da sociedade de economia mista e de suas subsidiárias que explorem atividade econômica de produção ou comercialização de bens ou de prestação de serviços, dispondo sobre:

I - sua função social e formas de fiscalização pelo Estado e pela sociedade;

II - a sujeição ao regime jurídico próprio das empresas privadas, inclusive quanto aos direitos e obrigações civis, comerciais, trabalhistas e tributários;

III - licitação e contratação de obras, serviços, compras e alienações,observados os princípios da administração pública;

IV - a constituição e o funcionamento dos conselhos de administração e fiscal, com a participação de acionistas minoritários;

$\mathrm{V}$ - os mandatos, a avaliação de desempenho e a responsabilidade dos administradores.

Verifica-se que tal alteração trouxe certa flexibilidade no que se refere à forma de contratação das empresas públicas e sociedades de economia mista, dando-Ihes mais autonomia. 
A partir da Constituição Federal Brasileira, de 1988, artigo 37, inciso XXI, a licitação recebeu status de princípio constitucional, de observância obrigatória pela Administração Pública direta e indireta de todos os poderes da União, Estados, Distrito Federal e Municípios (BRASIL, 2007):

ressalvados os casos específicos na legislação, as obras, serviços,
compras e alienações serão contratadas mediante processo de licitação
pública que assegure igualdade de condições a todos os concorrentes,
mantidas as condições efetivas da proposta, nos termos da lei, o qual
somente permitirá exigências de qualificação técnica e econômica
indispensáveis à garantia do comprimento das obrigações. (BRASIL,
2007, p.19).

O artigo acima citado foi regulamentado pela Lei n. 8.666 de 21 de junho de 1993, que tem por finalidade "estabelecer normas gerais sobre licitações e contratos administrativos pertinentes a obras, serviços [...] compras, alienações e locações no âmbito dos Poderes da União, dos Estados, do Distrito Federal e dos Municípios." (BRASIL, 1993).

O artigo 3ำ, da Lei 8.666/1993, estabelece que a licitação deve garantir o princípio constitucional da isonomia e selecionar a proposta mais vantajosa para a Administração e a promoção do desenvolvimento nacional sustentável, (BRASIL, 1993). Nesse artigo, são enumerados os princípios básicos que regem esse procedimento administrativo, dando-o transparência e estabelecendo os direitos e deveres de todos envolvidos nas compras públicas.

A contratação pela Administração Pública com a iniciativa privada, seja, de fornecimento de bens, materiais, serviços ou obras é como não poderia deixar de ser, um tema que merece nossa atenção por sua relevância e atualidade.

Para que a Administração Pública tenha como meta a modernização e a desburocratização de suas atividades nas contratações de bens e serviços, garantindo celeridade e economia, este estudo foi com foco no desenvolvimento de uma gestão estratégica mais eficiente, contemplando como um dos requisitos necessários o amparo legal.

A adesão à Ata de Registro de Preços é algo que deveria ser colocado em prática no âmbito da administração do Ministério da Defesa, em virtude das vantagens que apresenta, promove um sistema de gestão de compras mais customizado, melhorando o processo de logística no que se refere ao recebimento, armazenamento e estoque dos seus produtos. 
Conforme Fernandes (2006, p. 98), o serviço público não possui metas tão audaciosas pelo fato de lidar com recursos escassos ou não dispor de alta tecnologia, visto o volume de atividades não comportar um rigor científico, ou seja, na sua previsão, tampouco prever a vida útil de materiais de consumo. Tais dificuldades, assim como chefias despreparadas na elaboração de metas que não envolvem todas as áreas organização, colocam nos ombros dos responsáveis enormes pressões nas aquisições de bens e serviços, no que se refere ao tempo incompatível com os trâmites legais, além de nulidades ou contratações diretas sem licitação, sem as hipóteses legais previstas. Diante do surgimento da necessidade de contratação de bens e serviços, sem a utilização de meios burocráticos, vislumbrou-se a importância da realização deste estudo, que apresenta as vantagens da adesão à Ata de Registro de Preços.

Há nítidas vantagens na utilização desse procedimento: primeiro, porque motiva o uso do Sistema Registro de Preços- SRP por outros órgãos, aumentando a credibilidade do Sistema; segundo, porque motiva a participação, ou seja, quem tiver preços registrados e suportar novas demandas poderá ser contratado sem licitação por outro órgão ou entidade; e, terceiro, o procedimento é desburocratizante, pois fixa requisitos mínimos para a adesão.

Fernandes (2006, p. 421/422), relaciona os requisitos a seguir para adesão à Ata Registro de Preços:

1) Interesse do órgão não participante (carona) em utilizar a Ata de Registro de Preços;

2) Avaliação em processo próprio, interno do órgão não participante (carona) de que os preços e condições do SRP são mais vantajosos, fato que pode ser revelado em simples pesquisa;

3) Prévia consulta e anuência do órgão gerenciador;

4) Indicação pelo órgão gerenciador do fornecedor, com observância da ordem de classificação;

5) Aceitação, pelo fornecedor, da contratação pretendida, condicionada esta à ausência de prejuízo aos compromissos assumidos na Ata de Registro de Preços;

6) Embora a norma seja silente a respeito, deverão ser mantidas as mesmas condições do registro, ressalvadas apenas as renegociações promovidas pelo órgão gerenciador, que se fizerem necessárias;

7) Limitação da quantidade a cem por cento dos quantitativos registrados na Ata.

O citado art. 8 $^{\circ}$ do Decreto $\mathrm{n}^{\circ}$ 3.931, (BRASIL, 2001), preceitua que: a Ata de Registro de Preços, durante sua vigência, poderá ser utilizada por qualquer órgão ou entidade da Administração que não tenha participado 
do certame licitatório, mediante prévia consulta ao órgão gerenciador, desde que devidamente comprovada a vantagem.

Da leitura do artigo, nota-se que a vantagem econômica deve estar devidamente comprovada, entendendo-se que deve ser feita por meio de ampla pesquisa de preços praticados no mercado local e no âmbito da Administração Pública de bens ou serviços com especificações compatíveis com aquelas que se pretende contratar.

Nesse aspecto, registra-se ainda, que o Sistema de Registro de Preços, como procedimento especial de licitação, deve ser regido pelos princípios relacionados na Lei ํㅡ 8.666 , que preceitua no seu art. $3^{\circ}$ que:

A licitação destina-se a garantir a observância do princípio constitucional da isonomia e a selecionar a proposta mais vantajosa para a Administração e será processada e julgada em estrita conformidade com o princípio da legalidade, da impessoalidade, da moralidade, da igualdade, da publicidade, da probidade administrativa, da vinculação ao instrumento convocatório, do julgamento objetivo e dos que lhes são correlatos. Lei oํ 8.666, (BRASIL, 1993)

Interpretando-se teleologicamente a legislação de regência, pode-se constatar que o principal fundamento para a realização de procedimento licitatório pelos órgãos e entidades da Administração Pública é a obtenção da proposta mais vantajosa, concretizando-se assim o princípio da economicidade. $O$ procedimento de adesão, por sua vez, tem como escopo estender tal proposta, economicamente mais vantajosa, a outras entidades que necessitam de bens ou serviços semelhantes aos registrados, em quantidade igual ou menor do que a máxima prevista na Ata.

Segundo Fernandes (2006, p. 97) algumas vantagens efetivas e práticas do SRP foram evidenciadas por meio da sistematização das informações feitas por representantes de órgãos que, após conhecerem tais vantagens, demonstraram interesse e implantaram o Sistema, citando-as da forma mais imparcial possível: a não necessidade de dotação orçamentária.

A necessidade de previsão orçamentária para realização de certame licitatório é uma exigência da Lei de Licitações. Exigência de índole constitucional e tecnicamente correta. 
Assim, considerando-se tais explicações, conclui-se, quanto à primeira vantagem, de dotação orçamentária desnecessária, que, apesar da Lei de Licitação exigir previsão orçamentária para a realização do certame licitatório, conforme estabelece 0 art. $7^{\circ}$, infelizmente 0 governo libera as cotas intempestivamente de forma a não possibilitar o bom andamento do serviço, tendo o gestor muitas vezes que devolvê-las ao erário.

Para que tal procedimento não mais ocorresse, a Lei de Responsabilidade Fiscal (BRASIL, 2000), passou a dispor em seu art. $8^{\circ}$ que: "Até trinta dias após a publicação dos orçamentos, nos termos em que dispuser a lei de diretrizes orçamentárias e observadas o disposto na alínea do inciso I do art. 40, o Poder Executivo estabelecerá a programação financeira e o cronograma de execução mensal de desembolso".

Diante de tais considerações, verifica-se que, enquanto o sistema de licitação convencional exige a prévia dotação orçamentária, a adesão ao SRP não possui tal exigência, pois não há disposição legal expressa nesse sentido.

Quanto à segunda vantagem, o atendimento de demandas não previstas, pode-se verificar que poderá haver uma redução a um padrão mínimo do consumo de bens se houver um maior "rigor científico" do controle, assim como a utilização de estatísticas, o que não é feito pelo serviço público.

Outra vantagem que poderá ser verificada em estudos mais aprofundados é a redução do volume de estoque nos almoxarifados, buscando-se assim atingir o objetivo do justin time, qual seja: modernizar os estoques de forma a atender prontamente ou em curto espaço de tempo as demandas apresentadas.

Também como vantagem poderá haver uma redução do número de licitações feitas pelo órgão. Apesar de demandar um tempo maior no planejamento para a realização de uma licitação no formato do Sistema de Registro de Preços, se houver um bom planejamento, o número de recursos administrativos, materiais e humanos também serão reduzidos.

Por fim, pode-se considerar como a vantagem mais eficiente o tempo recorde da aquisição. Como geralmente os administradores não têm tempo hábil para planejar uma aquisição com eficiência, a solução para uma aquisição com bastante brevidade será o SRP. 
Faz-se necessário também o registro das desvantagens apresentadas, segundo salienta Fernandes (2006, p. 106): "É óbvio que também o sistema apresenta desvantagens, porque implica a mudança de uma cultura organizacional, esse é o passo mais difícil em qualquer instituição. Mais difícil e mais proveitoso!". Relaciona-as da seguinte forma:

As resistências à implantação têm oferecido os seguintes argumentos:

a) a complexidade da concorrência;

b) a necessidade de alocar recursos humanos para atualizar tabelas;

c) a impossibilidade de prevê todos os itens a serem adquiridos. (FERNANDES, 2006, p. 106).

\subsection{Princípios Básicos que Regem o Procedimento Administrativo}

\section{O Princípio da Legalidade}

Este princípio é um dos principais sustentáculos do Estado de Direito e uma das principais garantias de que os direitos individuais serão respeitados. Também é à base de todo o regime jurídico da Administração Pública, pois demonstra a subordinação da atividade administrativa à lei. Vejamos os dizeres de Mello (2000, p. 71):

O princípio da legalidade contrapõe-se, portanto, e visceralmente, a quaisquer tendências de exacerbação personalista dos governantes. Opõe-se a todas as formas de poder autoritário, desde o absolutista, contra o que irrompeu, até as manifestações caudilhescas ou messiânicas típicas dos países subdesenvolvidos. O princípio da legalidade é o antídoto natural do poder monocrático ou oligárquico, pois tem como raiz a idéia de soberania popular, de exaltação da cidadania. Nesta última se consagra a radical subversão do anterior esquema de poder assentado na relação soberano-súdito (submisso).

\section{O Princípio da Impessoalidade}

Di Pietro (2001, p. 71) defende que a impessoalidade da administração tanto pode significar que esse atributo deve ser observado em relação aos administrados como em relação à própria Administração. No segundo caso, o princípio significa que os atos administrativos são imputáveis não ao funcionário que os pratica, mas ao órgão público do qual o funcionário faz parte. No primeiro caso, o princípio relaciona-se à finalidade pública que deve nortear toda a atividade administrativa. Dado o escopo do presente trabalho, esse será o entendimento adotado e apenas a ele nos referiremos. 


\section{O Princípio da Moralidade}

Di Pietro (2001, p. 77-79) defende a idéia de que o desrespeito ao princípio da moralidade surgiu e se desenvolveu associado à idéia de desvio de poder, pois, em ambas as hipóteses, a Administração Pública se vale de meios lícitos para atingir finalidades meta jurídicas irregulares, ou seja, a imoralidade estaria na intenção do agente. Mais adiante, esse autor assevera que o princípio da moralidade obriga não apenas os administradores públicos, mas também o particular que se relaciona com a Administração Pública. Destaca que, em matéria de licitação, os conluios entre licitantes como um exemplo de ofensa ao princípio da moralidade.

\section{O Principio da Igualdade}

A igualdade de todos é um dos pilares do Estado de Direito. No que se refere às licitações públicas, esse princípio assegura a todos os interessados em contratar com a Administração o direito de competir nos certames licitatórios públicos. A Constituição Federal, no art. 37, inciso XXI, assegura igualdade de condições entre todos os concorrentes:

as obras, serviços, compras e alienações serão contratados mediante processo de licitação pública que assegure igualdade de condições a todos os concorrentes.

No entendimento de Meirelles (2003, p. 265), segundo o qual a igualdade entre os licitantes é princípio impeditivo da discriminação entre os participantes do certame, quer através de cláusulas que favoreçam uns em detrimento de outros, quer mediante julgamento faccioso, que desiguale os iguais ou iguale os desiguais. No entanto, o estabelecimento de requisitos mínimos nos editais e convites, quando colocados para garantir a execução do contrato, a segurança e a perfeição do serviço, não estabelece ofensa ao princípio da isonomia ou da igualdade. Segundo esse autor, se, todavia, configurado a quebra do princípio da isonomia na licitação, quer pelo favorecimento que pela perseguição a licitante, o edital ou o julgamento são passíveis de anulação.

\section{O Principio da Publicidade}

Este princípio, que também é explicitamente citado no art. 37 da Constituição Federal, preconiza, nos dizeres de Motta (2002, p. 112), a 
visibilidade dos atos da administração para viabilizar o exercício pleno do controle da parte da sociedade, contrariamente à visão segredista, que tende a dificultar o acesso a dados e documentos aos interessados e também a proclamar a desnecessidade de motivar os atos.

Prescreve este princípio o dever da Administração Pública de dar plena transparência de seus atos, exceto nos caos em que o sigilo se justifique por imprescindível à segurança da sociedade e do Estado, exceção permitida na Constituição Federal, art. 5’, inciso XXXIII.

Para atender a este princípio nas licitações públicas, quis o legislador que todas as suas fases, exceto o conteúdo das propostas, até a respectiva abertura, sejam públicas. Em outras palavras, o princípio da publicidade impõe a divulgação das diversas fases da licitação e faculta a qualquer interessado o acesso às licitações públicas e seu controle, garantindo com isso a lisura do pleito e o atendimento aos demais princípios administrativos. A transparência beneficia não apenas os licitantes, mas também a qualquer cidadão.

\section{O Princípio da probidade administrativa}

Motta (2002,), é a exigência de atuação ética dos agentes da Administração Pública em todas as etapas do procedimento. Ser probo é ser correto com o trato da coisa pública, não se desviando da finalidade da lei, nem se beneficiando da qualidade do cargo que exerce.

\section{O Princípio da Vinculação ao Instrumento Convocatório}

Por este princípio, ficam a Administração e os licitantes obrigados a observar as normas e condições estabelecidas no ato convocatório. Só será permitido fazer ou agir dentro dos limites previstos no edital. Conforme destaca Furtado (2001, p. 48), esse princípio consta do art. $3^{\circ}$ da Lei 8.666 (BRASIL, 1993) e é enfatizado no art. 41 da mesma Lei, que dispõe que "a Administração não pode descumprir as normas e condições do edital, ao qual se acha estritamente vinculada".

Meirelles (2003, p. 266) destacou de forma simples e definitiva que o edital é a lei interna da licitação, e, como tal, vincula aos seus termos tanto os licitantes quanto a Administração que o expediu. O edital é impositivo para ambas as partes e para todos os interessados na licitação. 


\section{O Princípio do Julgamento Objetivo}

De acordo com Motta (2002,) O julgamento é baseado em critérios objetivos indicados no edital, buscando afastar a discricionariedade no julgamento. A noção de critério de julgamento vincula-se ao conceito de tipo de licitação: menor preço; melhor técnica; técnica e preço; maior lance ou oferta.

\section{O Princípio da eficiência}

O princípio da eficiência, outrora implícito em nosso sistema constitucional, tornou-se expresso no caput do art. 37, em virtude de alteração introduzida pela Emenda Constitucional n. 19, (BRASIL, 1998).

É evidente que um sistema balizado pelos princípios da moralidade de um lado, e da finalidade, de outro, não poderia admitir a ineficiência administrativa. Bem por isso, a Emenda №. 19, no ponto, não trouxe alterações no regime constitucional da Administração Pública, mas, como dito, só explicitou um comando até então implícito.

Eficiência não é um conceito jurídico, mas econômico. Não qualifica normas, qualifica atividades. Numa idéia muito geral, eficiência significa fazer acontecer com racionalidade, o que implica medir os custos que a satisfação das necessidades públicas importam em relação ao grau de utilidade alcançado. Assim, o princípio da eficiência, orienta a atividade administrativa no sentido de conseguir os melhores resultados com os meios escassos de que se dispõe e a menor custo. Rege-se, pois, pela regra de consecução do maior benefício com o menor custo possível.

\subsubsection{Modalidades de Licitação}

\section{CONCORRÊNCIA}

A concorrência é a primeira modalidade de licitação, está prevista no $\S 1^{\circ}$, do art. 22 da Lei 8.666/93. Visa a participação de quaisquer de interessados e em qualquer número, desde que estes comprovem atender os requisitos mínimos de qualificação constantes no edital.

Meirelles (1999, p. 70) define assim a concorrência: "Concorrência é a modalidade de licitação própria para contratos de grande valor, em que se admite a participação de quaisquer interessados, registrados ou não, que satisfaçam as 
condições do edital, convocados com antecedência mínima de 45 ou 30 dias" (arts. $22, \S 1^{\circ}$, e $21, \S 2^{\circ}$ ).

A concorrência é a modalidade apropriada para contratos de grande valor, pois não há valor máximo que limite suas utilizações, podendo substituir tanto o convite como a tomada de preço. Na Administração Pública é exigida para compra de bens imóveis. Pode, também: ser exigida para a alienação de bens imóveis, desde que não seja adotado a modalidade de leilão; e para as concessões de uso, de serviço ou de obra pública e licitações internacionais, independente do valor do contrato(art. 23 , $\S \S 3^{\circ}$ e $4^{\circ}$ e art. 19, III, Lei 8.666, (BRASIL, 1993).

\section{TOMADA DE PREÇO}

Conforme Pereira (1997),é uma modalidade de licitação que exige licitantes previamente cadastrados, ou que se qualifiquem previamente no tempo cabível. Os valores a serem contratados limitam-se a $R \$ 1.500 .000,00$ (um milhão e quinhentos mil reais) para obras e serviços de engenharia (art. 23, inciso I, alínea 'b' da Lei $n^{\circ} 8,666 / 93$ ), e a $R \$ 650,000,00$ (seiscentos e cinqüenta mil reais) para compras e serviços que não sejam de engenharia.

A modificação imposta pela Lei $n^{\circ}$ 8.666, (BRASIL, 1993), permitiu a participação no certame daqueles interessados previamente inscritos, ou daqueles que se qualificarem até três dias antes do certame, no registro de cadastro administrativo, que é formado pelos registros de fornecedores de bens, executores de serviços de obras e serviços e são mantidos por órgãos e entidades administrativas que realizam licitações com freqüência (art. 34 e 37 da Lei $n^{\circ}$ 8.666, (BRASIL, 1993).

\section{CONVITE}

O convite é a modalidade de licitação mais simples e célere prevista na Lei $n^{\circ}$ 8.666, (BRASIL, 1993), sendo muito utilizada para as concentrações de pequeno valor, que são as previstas no art. 23, inciso I, alínea "a": obras e serviços de engenharia até $R \$ 150.000,00$ (cento e cinqüenta mil reais), e art. 23, inciso II, alínea "a": para compras e serviços que não seja de engenharia até $R \$$ $80.000,00$ (oitenta mil reais), com redação modificada pela Lei n 9.648, (BRASIL, 1998). 
Contudo, a prática tem mostrado que realizar outras modalidades de licitações como concorrência e tomada de preço, tem sido bem menos complicado do que processar o convite.

A sua simplicidade é comentada por Gasparini:

modalidade de licitação aberta sem publicidade, indicada para contrato de pequeno vulto, que exige o convite a, no mínimo, 3 (três) interessados escolhidos pela entidade obrigada a licitar e por ela tidos como habilitados e que permite a participação de interessados cadastrados que manifestarem interesse com a antecedência de até vinte e quatro horas da data designada para a apresentação das propostas (GASPARINI, 1995, p. 332)

\section{CONCURSO}

É modalidade especial de licitação, apesar de seguir alguns dos princípios do procedimento licitatórios, como os da publicidade e da igualdade entre os participantes, não seguirá as formalidades e exigências especificas da concorrência. Para Meirelles (1999, p. 89), o concurso como modalidade de licitação se presta "[...] à escolha de trabalho técnico ou artístico, predominantemente de criação intelectual. É usado comumente na seleção de projetos, onde se busca a melhor técnica, e não o menor preço [...]".

Segundo (DALLARI, 1997, p. 80):

Concurso é a definição de procedimento licitatório especificamente destinado à contratação de serviço técnico ou trabalho artístico, efetuado mediante convocação genérica de um número indeterminado de pessoas que aceitam a remuneração previamente estabelecida, cuja idoneidade pode ser verificada tanto previamente quanto no concurso do procedimento, como ainda após a classificação dos vencedores, e que, pela especificidade do objeto, exige publicidade adequada para atingir um número razoável de possíveis interessados.

\section{LEILÃO}

Este tipo de modalidade de licitação em que podem ser usados dois tipos de procedimento. O primeiro é o leilão, efetuado por um leiloeiro oficial e regido pela Legislação Federal pertinente, podendo, porém, ser a elaboração das condições específicas efetuada pela Administração Pública. O segundo tipo de leilão é o administrativo, que foi criado com a finalidade de pôr à venda 
mercadorias apreendidas como contrabando e ainda àquelas abandonadas nas alfândegas, nos armazéns das ferrovias ou nas repartições públicas.

O leilão pode, em caráter excepcional, nos moldes do $\S 5^{\circ}$, art. 22 da Lei no 8.666, (BRASIL, 1993), ser utilizado para a venda de bens imóveis e ainda para a venda de bens inservíveis, de acordo com o que preceitua $\circ \S 6^{\circ}$, art. 17 da mesma lei.

Gasparini definiu (1995, p. 335):

\begin{abstract}
"É a modalidade de licitação aberta com ampla publicidade, precipuamente indicada para a venda de bens móveis inservíveis ou de produtos lealmente apreendidos ou penhorados, que admite qualquer interessado, independentemente de habilitação, onde o vencedor é o que oferece maior lance, desde que igual ou superior à avaliação".
\end{abstract}

\title{
PREGÃo
}

O pregão é uma moderna modalidade de licitação, criada através da Medida Provisória n. 2.026, (BRASIL, 2000), e regulamentada pelo Decreto n.ำ 3.555, (BRASIL, 2000).

Em sentido literal, a palavra pregão corresponde ao ato de apregoar, significando proclamação pública. Antes dessa medida provisória, associava-se o pregão, no âmbito do Direito Administrativo, ao modo pelo qual se realiza o leilão, modalidade destinada à venda de bens móveis inservíveis para a Administração, ou legalmente apreendidos ou penhorados e até mesmo à alienação de bens móveis que venham a integrar o patrimônio de ente público em função de penhora ou dação em pagamento.

Tal nova modalidade de licitação, instituída através da referida Medida Provisória, destina-se à aquisição de bens e serviços comuns, promovida exclusivamente no âmbito da União, qualquer que seja o valor estimado da contratação, em que a disputa pelo fornecimento é feita por meio de propostas e lances em sessão pública.

Pretendeu-se, com a instituição do pregão, uma maior concentração, flexibilização e desburocratização do procedimento licitatório convencional. Ocorre em uma sessão pública, configurando uma disputa entre os licitantes através de propostas e lances. 
A regularização da Medida Provisória ํㅡㄹ 2026, (BRASIL, 2000), pela Lei no 10.520, (BRASIL, 2002), acrescenta uma nova modalidade de licitação. $O$ pregão é a modalidade de licitação para aquisição de bens e serviços comuns em que a disputa pelo fornecimento é feita em sessão pública, por meio de propostas e lances, para classificação e habilitação do licitante com a proposta de menor preço. A grande inovação do pregão se dá pela inversão das fases de habilitação e análise das propostas. Dessa forma, apenas a documentação do participante que tenha apresentado a melhor proposta é analisada.

A Lei do Pregão, em seu artigo 20, § 10, estabeleceu a realização do pregão por meio de recursos de tecnologia da informação, nos termos de regulamentação específica $O$ Decreto №. 5.450, regulamentou o pregão eletrônico e tornou a utilização da modalidade pregão obrigatória para a aquisição de bens e serviços comuns, sendo preferencial a utilização em sua forma eletrônica, aos órgãos da administração pública federal direta, os fundos especiais, as autarquias, as fundações públicas, as empresas públicas, as sociedades de economia mista e as demais entidades controladas direta ou indiretamente pela União, (BRASIL, 2005). A modalidade pregão, em sua forma eletrônica.

De acordo com Meirelles (2004, p.318), o método do pregão eletrônico "segue as regras básicas do pregão comum, mas como é evidente, deixa de ocorrer à presença física do pregoeiro e dos participantes, já que todas as comunicações são feitas via eletrônica".

Em regra é obrigatória a licitação antecedendo a contratação pública. Existem, no entanto, algumas conjecturas previstas nas normas gerais sobre licitações e contratos administrativos, que aceitam a realização de compras públicas sem a formalidade de Processos licitatórios. Existem duas situações em que isso se verifica: dispensa de licitação e inexigibilidade (BRASIL, 1993).

A dispensa de licitação acontece nas situações em que, apesar de existir viabilidade de competição, a Lei aprova a celebração direta da contratação licitação dispensável, ou nega a realização do processo - licitação dispensada. No art. 24, a Lei 8.666 (BRASIL, 1993) relaciona 29 (vinte e nove) situações na qual a o processo licitatório pode ser dispensável, nesta situação a Lei determina a não realização da licitação, permanecendo a juízo da autoridade Administrativa definir, em conformidade da conveniência, se realiza ou não o processo licitatório. 
Barros (1995) explica que com o processo licitatório, o legislador buscou garantir a contratação contra conluios, partindo da pressuposição ou do preconceito de que dirigentes e dirigidos não merecem confiança. Porem Mas os conluios subsistiu com a licitação. Essa impotência do instituto levou a doutrina a repetir o cotejo entre o risco de conluio que não deixa de existir e a perda de eficiência que passa a ter com a licitação, a fim de repetir o questionamento em face daquela hipótese de dúvida. Os balanços recentes são mais negativos que os precedentes, concluindo pela ineficácia da licitação perante os seus fins.

\subsection{Sistema de Registro de Preços}

O Sistema de Registro de Preços, conforme previsto no art. 15 da Lei de Licitações e Contratos, Lei № 8.666, (BRASIL, 1993), foi regulamentado pelo Decreto $n^{0}$ 3.931, (BRASIL, 2001) que, mais tarde, também sofreu alterações em alguns dispositivos pelo Decreto oㅜ 4.342, (BRASIL, 2002).

O Sistema de Registro de Preços, (SRP) segundo Leão (2001, p,35), "consiste num procedimento especial de licitação e contratação que pode ser adotado para compras cujos objetos consistam em materiais, produtos ou gêneros de consumo freqüente pelo Poder Público".

No entanto, Bittencourt (2003, p, 43) afirma que:

O SRP deve ser encarado simplesmente como uma ferramenta de auxílio que se consubstancia num procedimento especial a ser adotado nas compras do Poder Público, quando os objetos forem materiais, produtos ou gêneros de consumo freqüente, e ainda, em situações especialíssimas, nas contratações de serviços[...] diferentemente do procedimento adotado nas licitações comuns, no lugar de ocorrerem formulações de propostas específicas por parte dos licitantes, visando a um objeto unitário e perfeitamente definido, ocorrem proposições de preços unitários, que deverão vigorar por certo [...] período em que a Administração, baseada em conveniência e oportunidade, poderá realizar aquisições necessárias [...].

Bittencourt (2003, p.42) afirma que o "Registro de Preços significa a licitação não para compras imediatas, mas para eleição de cotações vencedoras, que, ao longo do prazo máximo de validade do certame podem ensejar, ou não, contratos de compras". 
Já para Bittencourt (2003, p. 47), o SRP destina-se às licitações para as compras e contratos freqüentes da Administração Pública, o que inquestionavelmente, agiliza e simplifica as aquisições e serviços, afastando entraves burocráticos que ocorrem nas licitações comuns.

É importante destacar que SRP não é uma modalidade de licitação, nem um tipo de processo licitatório, sim um conjunto de procedimentos para registro de preços de prestação de serviços ou de aquisição de bens, para futura contratação.

O SRP é um procedimento peculiar de licitação, que se efetiva pelas modalidades concorrência ou pregão, em que se pretende escolher a proposta mais vantajosa, com estrita observância nos princípios básicos de licitação, para futura e eventual contratação pela Administração Pública.

Também como definições, o Decreto № 3.931, (BRASIL, 2001) elenca as seguintes:

I. Sistema de Registro de preços - SRP - conjuntos de procedimentos para registro formal de preços relativos à prestação de serviços e aquisição de bens, para contratações futuras; (redação dada pelo Decreto $\mathrm{n}$ - 4.342, de 23.08.2002)

II Ata de Registro de Preços - documento vinculativo, obrigacional, com característica de compromisso para futura contratação, onde se registram os preços, fornecedores, órgãos participantes e condições a serem praticadas, conforme as disposições contidas no instrumento convocatório e propostas apresentadas.

III Órgão Gerenciador - órgão ou entidade da Administração Pública responsável pela a condução do conjunto do procedimento do certame para registro de preços e gerenciamento da Ata de Registro de Preços dele decorrente.; e

IV Órgão participante - órgão ou entidade que participa dos procedimentos iniciais do SRP e integra a Ata Registro de Preços.

\subsubsection{Registro de Preços}

É possível explorar mais as potencialidades do SRP, admitindo-se vários registros, com preços diferenciados, para um mesmo item.

Segundo Fernandes (2006), antes do Decreto 2.743, (BRASIL, 1998), podiam ser registrados vários preços para o mesmo material, em função da capacidade de fornecimento ou outro critério previsto no edital da concorrência, observado o limite máximo estabelecido. 
No entanto, na vigência do Decreto acima só se admitia um preço por registro. Após definido o licitante vencedor, a Administração consultava os demais fornecedores para, no caso de aceitarem fornecer pelo preço do primeiro colocado, registrá-los até atingir a quantidade máxima do edital.

O Decreto 3.931, (BRASIL, 2001) permitiu expressamente a adoção desse sistema quando dispôs que, excepcionalmente, o órgão gerenciador, poderá registrar os outros preços ofertados quando a quantidade do primeiro colocado não atender às demandas estimadas. Para isso, os objetos deverão ser de qualidade ou desempenho superior aos do vencedor, a Administração deverá justificar e comprovar a suas vantagens e os preços ofertados deverão ser inferiores ao máximo admitido.

No que pese essa possibilidade, "o Decreto oㅜ 3.931, (BRASIL, 2001), preferiu definir, como regra, ideia nova, diversa dos Sistemas de Registros de Preços". De acordo com o art. $6^{\circ}$, "ao preço do primeiro colocado poderão ser registrados tantos fornecedores quantos necessários para que, em função das propostas apresentadas, seja atingida a quantidade total estimada para $\mathrm{o}$ item ou lote", assim, a Administração estará sempre comprando pelo menor preço, sujeitando-se os interessados à proposta mais vantajosa. Admite-se o registro dos preços até a quantidade esperada pela Administração (FERNANDES, 2006).

\subsection{2 Órgão Gerenciador, Participante e Carona}

Vale apena saber que a relação entre órgão gerenciador e órgãos participantes ou não (caronas) deve ser colocada com regras claras de procedimento adequado que esta parceria, quando for conveniente, pode-se formalizar tais relações, elaborando um ato de colaboração, ou um documento de cooperação técnica.

O ato de colaboração é utilizado para regular as relações entre órgão gerenciador e órgãos participantes quando o primeiro não cobra qualquer remuneração dos órgãos participantes pelo uso da Ata. O termo de colaboração técnica ou convênio é empregado quando o órgão gerenciador cobra um pagamento dos órgãos participantes pela administração do Sistema de Registro de Preços (FERNANDES, 2006). 
O Decreto 3.931/01 não estabeleceu a possibilidade de ser ajustada remuneração entre o órgão gerenciador e os participantes e caronas, no entanto, para Fernandes (2006), essa possibilidade parece perfeitamente viável.

Os órgãos participantes têm algumas vantagens em relação aos caronas, já que suas expectativas de consumo estão previstas no ato convocatório. Eles têm o compromisso do fornecimento pelos fornecedores e podem requisitar todos os itens previstos no SRP, sem a necessidade de prévia autorização do órgão gerenciador, nem do fornecedor, para fazer uso na Ata.

Os caronas necessitam de prévia consulta e anuência do órgão gerenciador para utilização da Ata de Registro de Preços. Este indicará o fornecedor ou prestador de serviço, que poderá aceitar a contratação pretendida, condicionada a não gerar prejuízo aos compromissos assumidos.

Assegura Fernandes $(2006$, p. 331) que "embora a norma seja silente a respeito, deverão ser mantidas as mesmas condições do registro, ressalvadas apenas as renegociações promovidas pelo órgão gerenciador, que se fizerem necessárias".

Os caronas, todavia, possuem boa vantagem, tanto sobre o órgão gerenciador, quanto sobre os participantes, pois podem adquirir cem por cento do quantitativo registrado na Ata, conforme dispõe o $\S 3^{\circ}$ do artigo $8^{\circ}$ do Decreto 3.931, (BRASIL, 2001), diferentemente do que acontece com o órgão gerenciador e com os participantes, limitados à aquisição das quantidades previstas no edital do processo licitatório.

\subsubsection{Vantagens do Sistema Registro de Preços}

Uma das grandes vantagens desse sistema é a desnecessidade de dotação orçamentária para sua realização. A Lei 8.666/93 exige previsão orçamentária para realização de certame licitatório, no entanto, o governo contingência o orçamento, libera cotas trimestrais e deixa as maiores cifras para o final do exercício, o que impossibilita o gestor de concretizar, em curto espaço de tempo, o longo percurso burocrático da licitação. Com isso, são devolvidas ao Erário cifras que eram efetivamente necessárias ao bom andamento do serviço público. 
Com a sistemática do SRP, a Administração seleciona a proposta mais vantajosa apresentada no procedimento licitatório e aguarda a liberação dos recursos orçamentários para a efetivação da compra ou solicitação de serviço. Além do mais o SRP não obriga a Administração, como a licitação convencional, em que há um compromisso que só pode ser revogado ou anulado em caráter excepcional.

Essa flexibilidade propicia a redução do volume de estoques, tendência da atual Administração, que proporciona economia de espaço, recursos pessoais e financeiros. Fernandes (2006, p, 100) destaca que:

\begin{abstract}
A moderna contabilidade prevê níveis ótimos de estoque, nos quais o ganho de economia de escala não é desperdiçado (...). Busca-se, assim, o objetivo do Just in time: modernizar os estoques, de forma a atender prontamente ou em curto lapso temporal, as demandas apresentadas. (...) conforme estudo realizado, (SRP) reduziu, em média, numa só instituição, $70 \%$ dos estoques, com nível de satisfação entre bom e ótimo das unidades requerentes desse órgão.
\end{abstract}

Outra vantagem é o atendimento de demandas imprevisíveis, muito comum no serviço público, que não dispõe de tecnologia e rigor científico para a previsão da necessidade de consumo de bens dos diversos setores da instituição.

Por isso, o SRP é vantajoso, as margens de fatores imprevisíveis no consumo são amplamente toleráveis, podendo ficar muito aquém do limite mínimo permitido ou ir até aos $25 \%$ previstos na Lei 8666 , (BRASIL, 1993).

Outra vantagem é que o SRP contribui, também, para a abolição dos fracionamentos de despesa, anormalidade freqüente apontada pelos órgãos de controle interno e/ou externos. Esse problema deixa de existir, já que o órgão pode realizar uma licitação, nas modalidades concorrência ou pregão, para aquisição de tudo que necessita para o ano inteiro, enquadrando o que faltar na modalidade de licitação.

O SRP é muito proveitoso para a Administração Pública. Para Bittencout (2003, p, 48) "a adoção do SRP determina, com absoluta certeza, flagrante economia, além de ganho em agilidade e segurança, com pleno atendimento ao princípio da eficiência, recentemente elevado a princípio constitucional da Administração Pública". 
E ainda Fernandes (2006) é unânime entre os administradores públicos, após conhecer as vantagens do Sistema de Registro de Preços, o interesse em proceder à sua implantação.

Finalizando o, Sistema Registro de Preços é uma importante ferramenta para Administração Pública tornado-se menos burocráticos os processos de aquisição de bens e serviços para administração. Acata todos os princípios constitucionais previstos no caput do artigo 37 da CF (BRASIL, 1988), e proporcionando enorme economia de recursos processuais, financeiros e de pessoal, além da agilidade, qualidade relevante de acordo com o princípio da anualidade, aplicável ao Orçamento Público da União.

\subsection{Ata de Registro de Preços}

O inciso II do artigo 1ำ, parágrafo único do Decreto 3.931, (BRASIL, 2001), define como Ata de Registro de Preços - documento vinculativo, obrigacional, com característica de compromisso para futura contratação, onde se registram os preços, fornecedores, órgãos participantes e condições a serem praticadas, conforme as disposições contidas no instrumento convocatório e propostas apresentadas.

A Ata de Registro de Preços caracteriza-se como um futuro contrato de compromisso que a Administração Pública tem com seu provável fornecedor. Assim sendo, pode-se afirmar que a Ata não é contrato. Cabe ressaltar que pelo artigo 62 da Lei 8.666/93, a Ata de Registro de Preços não pode ser representada por outra forma de documento: carta-contrato, notas de empenho de despesa, autorização de compra ou ordem de execução de serviço.

Alguns autores consideram a Ata de Registro de Preços uma representação formal da relação desvantajosa para os fornecedores. Como observa Leão (2001) apud Bittencourt (2003).

A ata de registro de preços constitui-se como um verdadeiro "pacto leonino" em relação aos que têm seus preços registrados, uma vez que, apesar de os obrigar ao fornecimento de objeto até o limite máximo estimado para o consumo em um determinado período, caso haja a solicitação por parte da Administração, não impõe ao Poder Público nenhuma obrigatoriedade de compra.

Afinal, os órgãos participantes são os favorecidos do SRP, registrados na Ata, que participam dos procedimentos iniciais, como bem define o Decreto 3.931, 
(BRASIL, 2001), artigo 1ำ, parágrafo único, inciso IV. Órgãos não participantes ou "caronas" são aqueles que não participam da implantação do SRP, mas requererem, posteriormente, ao órgão gerenciador, o uso da Ata de Registro de Preços.

O caput do art. $8^{\circ}$ do decreto 3.931 , (BRASIL, 2001), elenca o seguinte:

A Ata de Registro de Preços, durante sua vigência, poderá ser utilizada por qualquer órgão ou entidade da Administração que não tenha participado do certame licitatório, mediante prévia consulta ao órgão gerenciador, desde que devidamente comprovada à vantagem.

Atenção especial deve ser dada ao texto do artigo, quanto à admissão de utilização da Ata de Registro de Preços, que é dirigida para "qualquer órgão ou entidade da Administração" e não especificamente a órgão da Administração Pública, visto que a Lei o 8.666, (BRASIL, 1993), faz diferenciação, consoante o disposto na citação dos seus incisos XI e XII do art. 6º, como se pode ver a seguir:

XI - Administração Pública - a administração direta e indireta da União, dos Estados, do Distrito Federal, e dos Municípios, abrangendo inclusive asa entidades com personalidade jurídica de direito privado sob controle do poder público e das fundações por ele instituídas ou mantidas.

XII - Administração - órgão, entidade ou unidade administrativa pela qual a Administração Pública opera atua concretamente.

A respeito da diferenciação menciona Barbosa, ao assinalar que o raio da abrangência da Ata de Registro de Preços reduz significativamente a utilização do "carona", que ficará restrita à esfera da unidade administrativa que realizou o registro, tal opinião é esposada por Barbosa (2008, p, 68), ao afirmar que:

Inexiste óbice na utilização do Sistema de Registro de Preços por órgão de poderes diversos, e, muito menos entre os da administração direta e as autarquias, empresas públicas e sociedades de economia mistas pertencentes à mesma esfera de governo. (Barbosa, 2008, apud FILHO e PAYÁ, p, 65).

Numa interpretação de Fernandes, (2006), a sistemática, contudo, como a Administração é órgão da Administração Pública, parece possível quanto à extensão além da esfera de governo. Assim um órgão municipal poderá, ser 
atendidos os requisitos, se servir de Ata de Registro de Preços federal e vice versa.

Por tais considerações, o carona vai exigir maiores cuidados no momento do seu planejamento para se evitar futuros riscos que envolvam a interpretação de tal texto, exigindo total confiança quanto à outra parte.

Nas entrevistas realizadas na no Ministério da Defesa, com Responsável pelas compras, não é uma prática do órgão a realização de adesão A Ata Registro de Preços, só, ocorrendo apenas em situações realmente de última instância, conforme se verifica no seu questionário de entrevista.

O Tribunal de Contas da União também se manifesta quanto à utilização do carona, demonstrando que não é a favor que ente da Administração Federal realiza a prática aderir Ata de Registro de Preços de entidade estadual e municipal, mesmo com a faculdade elencada no art. $8^{\circ}$ do Decreto 3931, (BRASIL, 2001), conforme trata o acórdão: Acórdão n. 3625/2011-2ª Câmara, TC-029.535/2010-7, relator. Ministro. Aroldo Cedraz, 1․06.2011 (BRASIL, 2011), que diz que "é vedada a adesão de órgão ou entidade federal a ata de registro de preços promovida por órgão ou entidade estadual ou municipal - "Por ferir o princípio da publicidade, é vedada a adesão de órgão ou entidade federal a ata de registro de preços promovida por órgão ou entidade estadual ou municipal".

O Tribunal adotou tal entendimento acima mencionado do Tribunal ao analisar representação na qual examinou possíveis irregularidades na execução no contrato 58.554/2010, firmado pela Amazonas Distribuidora de Energia S/A (Amazonas Energia), sociedade de economia mista federal, para terceirização de impressão descentralizada, com fornecimento de equipamentos, suprimentos e suporte técnico. Dentre elas, constou a adesão à ata de registro de preços gerenciada por órgãos estaduais (Secretaria de Estado da Fazenda do Amazonas e Comissão Geral de Licitação do Estado do Amazonas) por parte da entidade federal.

As distorções que vem sendo realizadas com a possibilidade do carona é que representantes comerciais do quadro da sociedade empresária detentora da ata de registro ou até mesmo consultorias especializadas possam vir a oferecer os produtos que se encontram registrados na ata. O que poderá a vir constituir um enorme balcão de negócios ou num incontrolável mercado paralelo às aquisições 
pelos órgãos públicos através de processos licitatórios. Tornando-se uma rede de corrupção incontrolável, tendo em vista que de forma adesão é desprovida de qualquer tipo de controle dos atos como a publicação, o decreto sequer mencionou sua necessidade. É cediço que a proteção do interesse e do patrimônio público, depende da efetiva aplicação dos mecanismos de controle à disposição da própria administração internamente, ou através de provocação do Poder Legislativo e Judiciário, para agir em defesa da moralidade e probidade administrativa.

Embora ainda não haja muito estudo sobre o assunto fica muita vezes a cargo das autoridades responsáveis em determinar a realização das compras, assim como ter a liberdade para decidir a respeito da oportunidade e conveniência da prática ou não do ato.

\section{MÉTODOS E TÉCNICAS DE PESQUISA}

De acordo com os objetivos, a pesquisa realizada é considerada descritiva, segundo Gil (2002, p.42), essas pesquisas "têm como objetivo primordial a descrição das características de determinada população ou fenômeno ou, então, o estabelecimento de relações entre variáveis".

A pesquisa também é qualitativa, segundo Richardson (1999, p. 90), esse tipo de pesquisa "pode ser caracterizada como a tentativa de uma compreensão detalhada dos significados e características situacionais apresentadas pelos entrevistados".

Na presente pesquisa foi realizada a revisão bibliográfica essencialmente em artigos científicos relativos à Administração Pública. Foram também analisadas a legislação brasileira e livros de caráter científico. Além de consultas em documentos específicos do Órgão Público onde realizou o estudo.

A pesquisa de campo foi realizada por meio de entrevistas informais com quatro servidores públicos responsáveis pelas compras do Ministério da Defesa, quais sejam: o Diretor da Administração Interna do Ministério da Defesa, o Ordenador de Despesas, o Assistente Jurídico e a Coordenadora de Licitações e Contratos. 


\subsection{Tipo e descrição geral da pesquisa}

Este estudo baseia-se na pesquisa bibliográfica, constituídos principalmente de livros e artigos científicos e legislação brasileira de acordo com os objetos da pesquisa. Esta pesquisa é do tipo descritiva, porque procura conhecer a realidade estudada, suas características, seus problemas. Pretende "descrever com exatidão os fatos e fenômenos de determinada realidade" (TRIVIÑOS, 1987, p.100,)

Gil ( 1994, p.49) assevera que:

a pesquisa bibliográfica reside no fato de permitir ao investigador a cobertura de uma gama de fenômenos muito mais ampla do que aquela que poderia pesquisar diretamente. Esta vantagem se torna particularmente importante quando o problema se pesquisa requer dados muito dispersos pelo espaço. Assim, um trabalho fundamentado nessas fontes tenderá a reproduzir ou mesmo a ampliar esses erros. Para reduzir esta possibilidade, convém aos pesquisadores assegurarem-se das condições em que os dados foram obtidos, analisar em profundidade cada informação para descobrir possíveis incoerências ou contradições e utilizar fontes diversas, cotejando as cuidadosamente.

De acordo com Gil (1994), é possível classificar as pesquisas em cinco categorias, a bibliográfica, a descritiva, a experimental, a exploratória e o estudo de caso, devendo ser utilizada aquela que melhor se enquadrar ao tema abordado, de forma que possa ser explicado e apresentado com maior clareza.

Levando-se em conta os fatos das classificações e definições de diferentes tipos de pesquisa, este estudo teve um caráter bibliográfico. Os dados primários foram obtidos através de entrevistas semi-estruturaras. Ainda segundo Gil (2002, p.117), este procedimento consiste na entrevista "guiada por uma relação de pontos de interesse que o entrevistador explora ao longo de seu curso". Vergara (2000, p. 55) expõe que "a entrevista pautada por pontos propicia uma maior profundidade acerca das questões envolvidas na pesquisa".

\subsection{Caracterização da organização, setor ou área}

O Ministério da Defesa, (MD), é o órgão do Governo Federal incumbido de exercer a direção superior das Forças Armadas, constituídas pela Marinha, pelo Exército e pela Aeronáutica. Uma de suas principais atribuições é o 
estabelecimento de políticas ligadas à defesa e à segurança do país, além da implementação da Estratégia Nacional de Defesa, em vigor desde dezembro de 2008.

Criado em 10 de junho de 1999, através da a Lei Complementar № 97 (BRASIL, 1999), o MD tem sob sua responsabilidade uma vasta e diversificada gama de assuntos, alguns dos quais de grande sensibilidade e complexidade, como as operações militares, o orçamento de defesa, políticas e estratégias para o setor e o serviço militar.

A estrutura organizacional do MD contempla quatro grandes segmentos, a saber: o Estado-Maior Conjunto das Forças Armadas (EMCFA); a Secretaria de Produtos de Defesa (Seprod); a Secretaria de Pessoal, Ensino, Saúde e Desporto (Sepesd) e a Secretaria de Coordenação e Organização Institucional (SEORI). Em 2011, o Ministério da Defesa passou a abrigar também o Centro Gestor e Operacional do Sistema de Proteção da Amazônia (Censipam), vinculado anteriormente à Casa Civil da Presidência da República.

Integra ainda a estrutura do MD, na qualidade de órgão subordinado, a Escola Superior de Guerra (ESG), centro de excelência em estudos de alto nível sobre defesa nacional, que se localiza na histórica Fortaleza de São João, no bairro da Urca, na cidade do Rio de Janeiro-RJ.

O detalhamento da estrutura organizacional do Ministério da Defesa, bem como a competência dos órgãos que o integram, encontra-se no Decreto no 7.364, (BRASIL, 2010), complementado pelo Decreto no 7. 476, (BRASIL, 2011).

A Secretaria de Coordenação e Organização Institucional (SEORI) é responsável pela direção dos serviços administrativos do MD, e é dirigida pelo Diretor Geral de Administração Interna (DEADI), onde está vinculado a Divisão Orçamentária e Financeira (DIOFI), subordinado a esta encontram-se a Coordenação de Licitação e Contratos, (COLIC).

Os membros entrevistados nessa pesquisa atuam no DEADI, na DIOFI e na COLIC, sendo a COLIC, a responsável por todo o procedimento licitatório do órgão até a realização da assinatura do contrato.

O MD iniciou a implantação do Sistema Registro de Preços desde setembro de 2001, na ocasião da entrada em vigor do Decreto 3.931, (BRASIL, 
2001). Atualmente a totalidade das aquisições é através de licitação na modalidade de pregão eletrônico pelo o Sistema Registro de Preços, raramente utiliza-se a adesão a Ata de Registro de Preços, mas, quando utiliza esta prática muita vezes motivo é que a aquisição é de caráter de urgência, não tendo tempo hábil para montar uma licitação tradicional.

\subsection{População e Amostra ou Participantes do Estudo}

Com o propósito de verificar o motivo pelo qual o Ministério da Defesa não ter a prática de aderir a Ata Registro de Preços, ou seja, ser "carona", foram realizadas entrevistas semi-estruturadas com quatro servidores envolvidos diretamente com as compras do órgão, foram eles: Diretor da Administração Interna do Ministério da Defesa, o Ordenador de Despesas, o Assistente Jurídico e a Coordenadora de Licitações e Contratos, já citados anteriormente. O objetivo de realizar a entrevista com tais pessoas foi pelo fato de terem um maior conhecimento sobre $\mathrm{o}$ assunto e, em consequência, seriam eles os que mais poderiam colaborar mais com os dados da pesquisa.

\subsection{Caracterização dos instrumentos de pesquisa}

A pesquisa foi realizada através da realização de uma entrevista destinada a uma população de quatro servidores que atuam no processo de compras do Ministério da Defesa. A utilização deste método possibilitou verificar os motivos pelos quais o Órgão não utiliza como pratica as adesões as Ata de Registro de Preços. As respostas dos entrevistados serviram de subsídios para complementar os fundamentos da pesquisa.

De acordo com o escopo da pesquisa e o referencial teórico foram definidos alguns assuntos chaves para servirem de roteiro no momento da aplicação da entrevista.

O roteiro de entrevista utilizado com os servidores do MD (Anexo I) foi elaborado com base nos assuntos chaves relacionado no quadro numero 1 abaixo, tendo com subsidio as bases teóricas, também dispostas no Quadro.

\begin{tabular}{|c|c|}
\hline Assunto & Base teórica \\
\hline Modalidade de licitação & (BRASIL, 1993) \\
\hline Sistema Registro de Preços & (BRASIL, 2001 e Fernandes, 2006) \\
\hline
\end{tabular}


Prazo de realização de licitação

Adesão a Ata Registro de Preços
(BRASIL, 1993 e BRASIL, 2002)

(Barbosa, 2008)

Quadro 1: assuntos para guiar a elaboração de roteiro para entrevista com servidores responsáveis pela compras do órgão. Elaborado pelo autor.

\subsection{Procedimentos de coleta e de análise de dados}

A efetivação do estudo ocorreu com a prévia anuência do Diretor de Administração Interna do Ministério da Defesa, o que possibilitou a elaboração da entrevista. Posteriormente, foram marcadas entrevistas individuais, diante das disponibilidades dos entrevistados. Foram realizadas as entrevistas em dias e horários diferenciados, num total de quatro, as entrevistas ocorreram nos dias 3, 5 e 7 de outubro de 2011 todas na parte da tarde, na sede do próprio órgão, MD.

As entrevistas tiveram duração aproximadamente de 40 (quarenta) minutos, por servidores.

As entrevistas se deram da seguinte forma: conforme as recomendações de Gaskell (2002), primeiro foi realizado uma pequena explanação do assunto, em seqüência foram apresentados qual seria o escopo da pesquisa, não foi permitida a gravação e a qualificação das pessoas entrevistadas.

As entrevistas foram guiadas pelo um rol de perguntas previamente relacionadas, ao término foi perguntado se teria algum a acrescentar como nada mais disse, foi encerrado a entrevista e realizado os agradecimentos pela a colaboração e o pesquisado disse que estaria disposição.

\section{RESULTADOS E DISCUSSÃO}

Será apresentado e discutido o resultado da pesquisa referente às entrevistas com os servidores escolhidos do MD. Foram entrevistados 4 (quatro) quatro servidores com faixa etária entre 27 e 62 anos de idade, todos com ampla experiência no assunto.

Foram analisados os dados coletados nas pesquisas e comparados com a legislação em vigor, no que se refere aos processos licitatórios, observa-se que são adotadas todas as regras que possibilitam a execução acertada dos processos licitatórios para aquisição de bens e serviços por parte do Ministério da Defesa.

Em relação ao problema da pesquisa, foi visto que o $\mathrm{MD}$, por fazer parte da administração direta, tem como órgão de controle externo o Tribunal de contas 
da União, órgão este que tem posicionamento contrário a adesão de Ata de Registro de Preços.

\subsection{Análises das Entrevistas}

Os servidores participantes desta pesquisa são pessoas que ocupam cargos de relevância no MD que atuam diretamente com as compras e aquisições de bens e serviços e possuem alto conhecimento no assunto, visto que tais cargos são de confiança e exigem qualificação profissional especial.

A seguir, estão elencadas as perguntas feitas aos entrevistados com o resumo das respostas.

Pergunta 1 Quais são as modalidades de licitação utilizada no Ministério da Defesa? Todos responderam que são as previstas nas leis em vigor, sendo acrescentado pelo o ordenador de Despesas que se tratando de bens e serviços comuns se utiliza a modalidade de Pregão Eletrônico

Pergunta 2 O MD no âmbito da Administração Federal Direta, cumpri o disposto no Decreto № 3931, de 19 de setembro de 2001? Responderam que por se tratar de Decretos na esfera Federal, não haveria motivos para não deixar de cumprir.

Pergunta 3 De acordo com o item II do artigo 15 da Lei 8666/93, as compras, sempre que possível deverão ser processada através de sistema de registro de preços o MD adota este sistema? Todos responderam que sim.

Pergunta 4 Não seria mais prático, eficiente e mais célere se o $M D$ aderisse uma Ata de Registro de Preços já licitada de outro Órgão? Na visão particular do Diretor sim ele comentou que se estivesse numa empresa privada com certeza adotaria essa prática, mas, como é funcionário de um órgão público tem que acatar as regras que o regem, o MD é auditado pelo o Tribunal de Contas da União, Instituição que não vê com bons olhos a utilização da Ata de Registro de Preços, desta forma ele acata a decisão.

O Ordenador de Despesas, já entende que poderia ser mais rápida e econômica as aquisições por esta prática, só como ele segue determinação superior,, também, acata as mesmas ordens. 
A Coordenadora já critica a não utilização desta prática para ela teria mais celeridade e economia, até porque está previsto na legislação vigente e a mesma ainda não foi revogada.

Para o assistente jurídico entende que o caráter da obrigatoriedade da licitação é duplamente violado, seja em relação à Administração que adere a Ata de Preços, sem ter promovido ou participado da licitação para o registro de preços, bem como em relação ao fornecedor beneficiário da Ata de Registro de Preços permitindo-o contratar com órgão sem participar de licitação promovida por este.

Também acrescentou que o carona tem sido muito útil para àquele administrador que não planeja, subvertendo a ordem correta dos atos necessários à aquisição de bens e serviços, constante na lei 8666/93. A aquisição de bens e serviços através da figura do carona é na maioria das vezes efetuada de "traz para frente", ou seja, em vista do produto constante na Ata e oferecido ao administrador é que este faz a verificação de suas necessidades, tendendo em considerá-lo adequado pela facilidade de sua aquisição sem procurar buscar outras alternativas que poderiam revelar-se mais eficientes ao atendimento ao interesse público.

Pergunta 5 Qual seria a desvantagem do MD em aderir uma Ata de Registro de Preços? Os três servidores responderam nenhuma e pelo contrario só teria vantagens, já o assistente jurídico diz que um órgão poderia se acomodar e ficar só pegando carona, desta forma deixaria de cumprir o que estabelece a Constituição Federal e a Leis de Licitação, recaindo no administrador todas as responsabilidades de improbidade administrativa.

Pergunta 6 Quantas licitações foram realizadas no ano de 2010, através Pregão Eletrônico? Esta resposta foi dada somente pelos Diretor, Ordenador e Coordenadora, um total de 73 , conforme consta divulgada no portal do Comprasnet Anexo "A".

A Constituição Federal de 1988 instituiu a obrigatoriedade de se realizar licitação prévia nos termos do artigo 37 inciso XXI, que preceitua: "XXI ressalvados os casos especificados na legislação, as obras, serviços, compras e alienações serão contratados mediante processo de licitação pública que assegure igualdade de condições a todos os concorrentes". 
Por sua vez a Lei 8.666, (BRASIL, 1993), prevê em seu artigo 22, licitação nas modalidades concorrência, tomada de preços; convite; concurso; e leilão e dispõe ainda no $\S 8 \cong$ do referido artigo: "É vedada a criação de outras modalidades de licitação ou a combinação das referidas neste artigo".

A Lei 10.520, (BRASIL, 2002), de igual hierarquia da 8.666/93, convertendo Medida Provisória criou a modalidade Pregão destinada à aquisição de bens e serviços comuns.

A licitação pelo Sistema de Registro de Preços (SRP) pode ser realizada nas modalidades Concorrência Pública (§ $3^{\circ}$ do artigo 15 da Lei 8666/93) ou Pregão (artigo 11 da Lei 10.520/02).

O decreto 3.931, (BRASIL,2001), permite a um órgão administrativo que não promoveu ou participou da licitação para o registro de preços beneficiar-se da Ata de Registro de outro órgão mediante prévia consulta e que o fornecedor e desde que o beneficiário da ata aceite lhe fornecer o objeto, tudo sem que tenha participado da elaboração do projeto básico ou termo de referência, como é o caso do órgão promotor ou participante que obrigatoriamente deve cumprir estes requisitos previstos na Lei 8666/93.

Esta aceitação invariavelmente ocorrerá pela vantajosidade de utilização da economia de escala que opera em favor do fornecedor. O procedimento que vem sendo apelidado, como carona está previsto expressamente no artigo $8^{\circ}$ do referido Decreto:

Art. 8ํ A Ata de Registro de Preços, durante sua vigência, poderá ser utilizada por qualquer órgão ou entidade da Administração que não tenha participado do certame licitatório, mediante prévia consulta ao órgão gerenciador, desde que devidamente comprovada à vantagem.

$\S 1^{\circ}$ Os órgãos e entidades que não participaram do registro de preços, quando desejarem fazer uso da Ata de Registro de Preços, deverão manifestar seu interesse junto ao órgão gerenciador da Ata, para que este indique os possíveis fornecedores e respectivos preços a serem praticados, obedecida a ordem de classificação.

$\S$ 2ํㅡㄹ Caberá ao fornecedor beneficiário da Ata de Registro de Preços, observadas as condições nela estabelecidas, optar pela aceitação ou não do 
fornecimento, independentemente dos quantitativos registrados em Ata, desde que este fornecimento não prejudique as obrigações anteriormente assumidas.

$\S 3^{\circ}$ As aquisições ou contratações adicionais a que se refere este artigo não poderão exceder, por órgão ou entidade, a cem por cento dos quantitativos registrados na Ata de Registro de Preços.

Diante do dispositivo em tela verifica-se que um órgão poderá adquirir bens ou serviços sem ter participado de qualquer licitação, este procedimento ofende literalmente ao disposto no artigo 37 da Constituição Federal, pois é uma espécie de substitutivo legal do procedimento licitatório, não permitido constitucional ou legalmente, utilizado como forma de exclusão da licitação. $O$ procedimento licitatório, salvo as exceções legais (dispensa e inexigibilidade), é condição obrigatória para a Administração Pública adquirir bens e serviços segundo Hely Lopes Meirelles.

O Ministério adota a linha da Advocacia Geral da União e do Tribunal de Contas da União que orienta utilizar o recurso previsto no art. 8을 do Decreto 3931 em raríssima situação e com justificativas circunstanciadas.

Da analise da entrevista verificasse que existem barreiras impostas pelos órgãos de controle no qual os servidores responsáveis pelo procedimento licitatório do Ministério da Defesa são obrigados a cumprir, embora tenha o poder discricionário para adotarem outras medidas alternativas.

Neste caso seria necessária revisão de tal Lei além de ajustes necessários à medida, de forma que fossem bem interpretadas pelos órgãos de controles e em conseqüência pelos gestores ficando alinhada em conseqüência a Administração poderia usufruir das vantagens que o art. 8o do Decreto 3.931, (BRASIL, 2001) oferece.

\section{CONCLUSÕES E RECOMENDAÇÕES}

O presente trabalho teve como escopo principal identificar as vantagens da adesão à Ata de Registro de Preços como instrumento e ferramenta administrativa adequada nas contratações Públicas.

Para alcançar os objetivos, foi utilizado o método de pesquisa de campo. A pesquisa de campo foi realizada por meio de entrevistas semi-estruturadas com 
servidores públicos do órgão responsáveis pela autorização das aquisições e contratações do Ministério da Defesa. A intenção era analisar as vantagens da adesão à Ata de Registro de Preços e o motivo que o MD, não utilizava tal ferramenta como uma rotina.

A literatura e a legislação especifica, relativas às contratações na esfera da Administração Pública comprova algumas vantagens da utilização do Sistema Registro de preços e em particular na adesão a Ata Registro de preços, ou seja, o carona, vantagem que tem de realizar aquisições e contratações de bens e serviços sem realizar licitação dentro do órgão. Embora tal vantagem esteja capituladas na legislação brasileira, existem correntes que não encara como dispositivo legal, tendo em vista que quem pega carona, não realiza processo licitatório, mas está previsto nos ditames da Lei.

Ao analisar as entrevistas dos servidores do órgão público ficou mais claro o entendimento por que o MD, não utiliza como prática a adesão a Ata Registro de Preços, por que o Órgão adota a mesma linha de raciocínio dos Órgãos de controle, que são eles: o Tribunal de Contas da União, TCU, e a Advocacia Geral da União, AGU, que entendem que o art. 8o do Decreto 3931 (BRASIL, 2001), pode levar um órgão a cometer ilegalidade no processo de licitação.

Em relação ao Sistema de Registro de Preços, o Ordenador de Despesas ressaltou a vantagem da economia de escala para ele é uma das maiores vantagens do Registro de preços quando este procedimento é realizado com a participação de vários órgãos, é a economia de escala que é obtida em razão do grande quantitativo licitado. No entanto é importante frisar que para se alcançar tal economia é fundamental que o planejamento da Administração seja correto para não frustrar as expectativas dos fornecedores.

Desta forma, os resultados encontrados admitem afirmar que na adesão a Ata de Registro de Preços, apresenta vantagens, no tocante a tempo e economia para o Órgão, porém não é ferramenta prioritária nas contratações, por se entender que a legislação é controvérsia.

De qualquer sorte os objetivos foram alcançados, tendo em vista ter-se chegado à resposta do por que não se utiliza como prática comum as adesões por parte do Ministério de Defesa. 
Já que existe a vantagem nesta prática seria de grande importância que a matéria fosse estuda com mais profundidade, de modo que todos os órgãos adotassem esta medida e não cometesse improbidade administrativa.

Cabe lembrar aqui os princípios legais que devem permear o ato licitatório com maior destaque para probidade administrativa que busca a promoção da seleção de forma mais acertada e transparente possível, agindo assim a Administração com os todos licitantes.

As leis não nascem sempre perfeitas, e para isso existem mecanismos para aprimorá-las. E é isso que esperamos que aconteça. A lei em geral é boa e bem vinda, porém não pode criar distorções que transformem os processos licitatórios em oportunidades de se manchar o mercado da livre e sadia concorrência.

Apesar das promessas de um ambiente favorável, a prática das compras governamentais ainda está um pouco distante do ideal. A legislação ainda apresenta uma série de distorção que impede ao gestor trabalhar com mais eficiência e eficácia.

Os dados apresentados nesta monografia permitiram conhecer as características das legislações em vigor e a divergência de interpretada pelos seus autores.

De qualquer sorte a pesquisa conseguiu atingir seu objetivo, e respondeu o problema de pesquisa. Apesar de pouco tempo e de literatura a escassa, conseguiu gerar conhecimento suficiente para reger os trabalhos proposto no tocante ao processo de compras do Ministério da Defesa.

Quanto aos processos de compras governamentais, este segmento pela sua importância, deveria contar com um processo contínuo de aperfeiçoamento da legislação para sua evolução, com a finalidade de dar mais celeridade, eficácia e eficiência nas compras públicas.

Sugere-se, para que os estudos avancem no meio acadêmico, e que a ferramenta prevista no artigo 8 $^{\circ}$ do Decreto 3.391, que versa sobre adesão a Ata de Registro de Preços, seja analisado em outros órgãos da Administração Pública. Nesse sentido, essa ferramenta de gestão ganhe especial relevância 
para as organizações públicas comprovando que a ferramenta e de extrema eficácia e eficiente na estratégia de gestão administrativa.

Concluo que a adesão a Ata de Registro de Preços nas contratações de bens e serviços no âmbito da Administração Pública pode ser uma grande evolução nas contratações públicas, sendo instrumento essencial para viabilizar grande parte das políticas que atendem diretamente à população, como a aquisição de remédios, livros didáticos, material e merenda escolar. Fundamentado sempre no princípio da eficiência, que é o mais moderno princípio da função administrativa, que já não se contenta em ser desempenhada apenas com legalidade, exigindo resultados positivos para o serviço público e satisfatório atendimento do interesse público. 


\section{REFERÊNCIAS}

BARBOSA, Paulo Rui. Sistema de Registro de Preços - SRP. Coleção 10 Anos de Pregão. Curitiba: Negócios Públicos, 2008.

BARROS, Sérgio Resende de. Liberdade e Contrato: a crise da licitação. Piracicaba: Unimep, 1995.

BITTENCOURT, Sidney. Licitação de Registro de Preços. 1. ed. Rio de Janeiro: Temas \&ldéias, 2003.

BRASIL Decreto 4.342 de 23/08/2002 - Disponível em http://www6.senado.gov.br/sicon/index.jsp, acesso em 23 nov 2011. Tribunal de Contas da União Acórdão n.ํㅜ 3625/2011-2a Câmara, TC029.535/2010-7, relator. Ministro. Aroldo Cedraz, 1․06.2011 (BRASIL, 2011).

BRASIL. Constituição da República Federativa do Brasil. (1988),. Disponível em http://www6.senado.gov.br/sicon/index.jsp, acesso em 23 nov 2011.

Decreto 2.743 de 21/08/1998. Disponível em http://www6.senado.gov.br/sicon/index.jsp, acesso em 23 nov 2011.

Decreto 3.931, de 19/09/2001. Disponível em http://www6.senado.gov.br/sicon/index.jsp, acesso em 23 nov 2011.

Decreto $\mathbf{7 . 3 6 4}$ de 23/11/2010. Disponível em http://www6.senado.gov.br/sicon/index.jsp, acesso em 23 nov 2011.

Decreto 7.476 de 10/05/2011. - Disponível em http://www6.senado.gov.br/sicon/index.jsp, acesso em 23 nov 2011. .Decreto 3.555, de 08/08/2000 Disponível em http://www6.senado.gov.br/sicon/index.jsp, acesso em 23 nov 2011.

.Decreto $\quad 5.450, \quad 31 / 05 / 2005 . \quad$ Disponível em http://www6.senado.gov.br/sicon/index.jsp, acesso em 23 nov 2011.

.Emenda Constitucional 19 de 04/06/1998 - Disponível em http://www6.senado.gov.br/sicon/index.jsp, acesso em 23 nov 2011.
Lei
$2.221 \mathrm{de}$
30/12/1909.
Disponível
em

http://www6.senado.gov.br/sicon/index.jsp, acesso em 23 nov 2011. 
.Lei Complementar 97 de 09/06/1999. Disponível em http://www6.senado.gov.br/sicon/index.jsp, acesso em 23 nov 2011.

.Lei Complementar 101, de 4 de maio de 2000. Disponível em http://www6.senado.gov.br/sicon/index.jsp, acesso em 23 nov2011

Lei 10.520 de 17/07/2002. Disponível em

http://www6.senado.gov.br/sicon/index.jsp, acesso em 23 nov 2011.

.Lei 8.666 de 21/06/1993. Disponível em

http://www6.senado.gov.br/sicon/index.jsp, acesso em 23 nov 2011.

.Medida Provisória $2.026-001$ de 01/06/2000. Disponível em http://www6.senado.gov.br/sicon/index.jsp, acesso em 23 nov 2011.

DALLARI, Adilson Abreu, Aspectos Jurídicos da Licitação, 4. ed.São Paulo Saraiva 1997.

DI PIETRO, Maria Sylvia Zanella. Direito Administrativo. 13. ed. São Paulo: Atlas, 2001.

FERNANDES, Jorge Ulisses JacobySistema de Registro de Preços e Pregão Presencial e Eletrônico. 2. ed. rev. e ampl. - 2. tiragem. Belo Horizonte: Fórum, 2006.

FURTADO, Lucas Rocha. Curso de licitações e contratos administrativos: teoria, prática e jurisprudência. São Paulo: Atlas, 2001.

GASKELL, G. Pesquisa qualitativa com texto, imagem e som: um manual prático. Petrópolis, RJ: Vozes, 2002.

GASPARINI, Diogenes. Direito administrativo. 4. ed. São Paulo: Saraiva, 1995.

GIL, A. C. Como elaborar projetos de pesquisa. 4. ed. São Paulo: Atlas, 2002.

PEREIRA, Junior Torres J., Comentário á Lei das Licitações e Contratações da Administração Pública, 4. Ed Ver, Rio de Janeiro, Renovar, 1997.

LEÃO, Eliana Goulart. O Sistema de Registro de Preços: Uma Revolução nas Licitações. 2. ed. rev. e atual. Brasília: Brasília Jurídica, 2001.

MEIRELLES, Hely Lopes. Direito Administrativo brasileiro, 29. ed. atual. São Paulo:Malheiros, 2004.

Direito Administrativo Brasileiro. 21. ed. São Paulo: Malheiros, 2003 
Licitação e Contratos Administrativos. 12 ed. atual. São Paulo: Malheiros Editores, 1999.

MELLO, Celso Antônio.Bandeira de Curso de Direito Administrativo. 12. ed. São Paulo: Malheiros, 2000.

MOTTA, C. P. C. Eficácia nas licitações e contratos. 9. ed. Belo Horizonte: Del Rey, 2002.

MUKAI, Toshio. Licitações e contratos públicos. 5. ed. São Paulo: Saraiva, 1999.

NUNES, J.; LUCENA, R.L.; SILVA, O.G. Vantagens e desvantagens do pregão na gestão de compras no setor público:, Brasília, abr./jun. 2007.

RICHARDSON, R. J. Pesquisa social: métodos e técnicas. São Paulo: Atlas, 1989.

TRIVIÑOS, Augusto N. S. Introdução à pesquisa em ciências sociais: a pesquisa qualitativa em educação. São Paulo: Atlas, 1987.

VERGARA, S.C. Projetos e relatórios de pesquisa em administração. 3. ed. São Paulo: Atlas, 2000. 


\section{Apêndice " $A$ " Roteiro da entrevista semi-estruturada}

1. Quais são as modalidades de licitação utilizada no Ministério da Defesa?

2. $\mathrm{O} M D$ no âmbito da Administração Federal Direta, cumpri o disposto no Decreto ํㅡ 3931, de 19 de setembro de 2001?

3. de acordo com o item II do artigo 15 da Lei 8666/93, as compras, sempre que possível deverão ser processada através de sistema de registro de preços o MD adota este sistema?

4. Não seria mais prático, eficiente e mais célere se o MD aderisse uma Ata de Registro de Preços já licitada de outro Órgão?

5. Qual seria a desvantagem do MD em aderir uma Ata de Registro de Preços?

6. quantas licitações foram realizadas no ano de 2010, através Pregão Eletrônico?

ANEXO "A"quadro das quantidades de licitações realizadas em 2010, conforme portal do www.comprasnet.gov.br

\begin{tabular}{|c|c|c|c|c|}
\hline No do Pregão & \multicolumn{2}{|c|}{$\begin{array}{c}\text { Cód. UASG } \\
\text { (Unid. de Compra) }\end{array}$} & $\begin{array}{c}\text { Nome da UASG } \\
\text { (Unid. de Compra) }\end{array}$ & $\begin{array}{c}\text { Data de } \\
\text { Realização }\end{array}$ \\
\hline 12010 & 110404 & DEPARTAMENTO DE ADMINISTRAÇÃO INTERNA & $27 / 01 / 2010$ \\
\hline
\end{tabular}




\begin{tabular}{|c|c|c|c|}
\hline$\underline{22010}$ & 110404 & DEPARTAMENTO DE ADMINISTRAÇÃO INTERNA & $03 / 03 / 2010$ \\
\hline$\underline{32010}$ & 110404 & DEPARTAMENTO DE ADMINISTRAÇÃO INTERNA & $18 / 03 / 2010$ \\
\hline$\underline{42010}$ & 110404 & DEPARTAMENTO DE ADMINISTRAÇÃO INTERNA & $16 / 03 / 2010$ \\
\hline$\underline{52010}$ & 110404 & DEPARTAMENTO DE ADMINISTRAÇÃO INTERNA & $17 / 03 / 2010$ \\
\hline$\underline{72010}$ & 110404 & DEPARTAMENTO DE ADMINISTRAÇÃO INTERNA & $06 / 04 / 2010$ \\
\hline$\underline{82010}$ & 110404 & DEPARTAMENTO DE ADMINISTRAÇÃO INTERNA & $13 / 04 / 2010$ \\
\hline$\underline{92010}$ & 110404 & DEPARTAMENTO DE ADMINISTRAÇÃO INTERNA & $03 / 05 / 2010$ \\
\hline 102010 & 110404 & DEPARTAMENTO DE ADMINISTRAÇÃO INTERNA & $28 / 04 / 2010$ \\
\hline$\underline{112010}$ & 110404 & DEPARTAMENTO DE ADMINISTRAÇÃO INTERNA & $30 / 04 / 2010$ \\
\hline$\underline{122010}$ & 110404 & DEPARTAMENTO DE ADMINISTRAÇÃO INTERNA & $04 / 05 / 2010$ \\
\hline$\underline{132010}$ & 110404 & DEPARTAMENTO DE ADMINISTRAÇÃO INTERNA & $07 / 05 / 2010$ \\
\hline 142010 & 110404 & DEPARTAMENTO DE ADMINISTRAÇÃO INTERNA & $11 / 05 / 2010$ \\
\hline$\underline{152010}$ & 110404 & DEPARTAMENTO DE ADMINISTRAÇÃO INTERNA & $19 / 05 / 2010$ \\
\hline$\underline{162010}$ & 110404 & DEPARTAMENTO DE ADMINISTRAÇÃO INTERNA & $18 / 05 / 2010$ \\
\hline$\underline{172010}$ & 110404 & DEPARTAMENTO DE ADMINISTRAÇÃO INTERNA & $20 / 05 / 2010$ \\
\hline 182010 & 110404 & DEPARTAMENTO DE ADMINISTRAÇÃO INTERNA & $25 / 05 / 2010$ \\
\hline$\underline{192010}$ & 110404 & DEPARTAMENTO DE ADMINISTRAÇÃO INTERNA & $31 / 05 / 2010$ \\
\hline$\underline{202010}$ & 110404 & DEPARTAMENTO DE ADMINISTRAÇÃO INTERNA & $26 / 05 / 2010$ \\
\hline$\underline{212010}$ & 110404 & DEPARTAMENTO DE ADMINISTRAÇÃO INTERNA & $07 / 06 / 2010$ \\
\hline$\underline{222010}$ & 110404 & DEPARTAMENTO DE ADMINISTRAÇÃO INTERNA & $14 / 06 / 2010$ \\
\hline$\underline{232010}$ & 110404 & DEPARTAMENTO DE ADMINISTRAÇÃO INTERNA & $14 / 06 / 2010$ \\
\hline$\underline{242010}$ & 110404 & DEPARTAMENTO DE ADMINISTRAÇÃO INTERNA & $15 / 06 / 2010$ \\
\hline$\underline{252010}$ & 110404 & DEPARTAMENTO DE ADMINISTRAÇÃO INTERNA & $16 / 06 / 2010$ \\
\hline$\underline{262010}$ & 110404 & DEPARTAMENTO DE ADMINISTRAÇÃO INTERNA & $21 / 06 / 2010$ \\
\hline$\underline{272010}$ & 110404 & DEPARTAMENTO DE ADMINISTRAÇÃO INTERNA & $01 / 07 / 2010$ \\
\hline$\underline{282010}$ & 110404 & DEPARTAMENTO DE ADMINISTRAÇÃO INTERNA & $21 / 07 / 2010$ \\
\hline$\underline{292010}$ & 110404 & DEPARTAMENTO DE ADMINISTRAÇÃO INTERNA & $05 / 07 / 2010$ \\
\hline$\underline{302010}$ & 110404 & DEPARTAMENTO DE ADMINISTRAÇÃO INTERNA & $08 / 07 / 2010$ \\
\hline$\underline{312010}$ & 110404 & DEPARTAMENTO DE ADMINISTRAÇÃO INTERNA & $29 / 07 / 2010$ \\
\hline$\underline{322010}$ & 110404 & DEPARTAMENTO DE ADMINISTRAÇÃO INTERNA & $20 / 07 / 2010$ \\
\hline$\underline{332010}$ & 110404 & DEPARTAMENTO DE ADMINISTRAÇÃO INTERNA & $26 / 07 / 2010$ \\
\hline$\underline{342010}$ & 110404 & DEPARTAMENTO DE ADMINISTRAÇÃO INTERNA & $28 / 07 / 2010$ \\
\hline$\underline{352010}$ & 110404 & DEPARTAMENTO DE ADMINISTRAÇÃO INTERNA & $12 / 08 / 2010$ \\
\hline$\underline{362010}$ & 110404 & DEPARTAMENTO DE ADMINISTRAÇÃO INTERNA & $16 / 08 / 2010$ \\
\hline$\underline{372010}$ & 110404 & DEPARTAMENTO DE ADMINISTRAÇÃO INTERNA & $18 / 08 / 2010$ \\
\hline$\underline{382010}$ & 110404 & DEPARTAMENTO DE ADMINISTRAÇÃO INTERNA & $16 / 08 / 2010$ \\
\hline$\underline{392010}$ & 110404 & DEPARTAMENTO DE ADMINISTRAÇÃO INTERNA & $18 / 08 / 2010$ \\
\hline$\underline{402010}$ & 110404 & DEPARTAMENTO DE ADMINISTRAÇÃO INTERNA & $30 / 08 / 2010$ \\
\hline$\underline{412010}$ & 110404 & DEPARTAMENTO DE ADMINISTRAÇÃO INTERNA & $10 / 09 / 2010$ \\
\hline$\underline{422010}$ & 110404 & DEPARTAMENTO DE ADMINISTRAÇÃO INTERNA & $21 / 09 / 2010$ \\
\hline$\underline{432010}$ & 110404 & DEPARTAMENTO DE ADMINISTRAÇÃO INTERNA & $21 / 09 / 2010$ \\
\hline$\underline{442010}$ & 110404 & DEPARTAMENTO DE ADMINISTRAÇÃO INTERNA & $27 / 09 / 2010$ \\
\hline$\underline{452010}$ & 110404 & DEPARTAMENTO DE ADMINISTRAÇÃO INTERNA & $24 / 09 / 2010$ \\
\hline$\underline{462010}$ & 110404 & DEPARTAMENTO DE ADMINISTRAÇÃO INTERNA & $29 / 09 / 2010$ \\
\hline$\underline{472010}$ & 110404 & DEPARTAMENTO DE ADMINISTRAÇÃO INTERNA & $04 / 10 / 2010$ \\
\hline$\underline{482010}$ & 110404 & DEPARTAMENTO DE ADMINISTRAÇÃO INTERNA & $21 / 10 / 2010$ \\
\hline$\underline{492010}$ & 110404 & DEPARTAMENTO DE ADMINISTRAÇÃO INTERNA & $21 / 10 / 2010$ \\
\hline$\underline{502010}$ & 110404 & DEPARTAMENTO DE ADMINISTRAÇÃO INTERNA & $27 / 10 / 2010$ \\
\hline$\underline{512010}$ & 110404 & DEPARTAMENTO DE ADMINISTRAÇÃO INTERNA & $27 / 10 / 2010$ \\
\hline$\underline{522010}$ & 110404 & DEPARTAMENTO DE ADMINISTRAÇÃO INTERNA & $05 / 11 / 2010$ \\
\hline$\underline{532010}$ & 110404 & DEPARTAMENTO DE ADMINISTRAÇÃO INTERNA & $11 / 11 / 2010$ \\
\hline
\end{tabular}




\begin{tabular}{|c|c|c|c|}
\hline$\underline{542010}$ & 110404 & DEPARTAMENTO DE ADMINISTRAÇÃO INTERNA & $17 / 11 / 2010$ \\
\hline$\underline{552010}$ & 110404 & DEPARTAMENTO DE ADMINISTRAÇÃO INTERNA & $18 / 11 / 2010$ \\
\hline$\underline{562010}$ & 110404 & DEPARTAMENTO DE ADMINISTRAÇÃO INTERNA & $19 / 11 / 2010$ \\
\hline$\underline{572010}$ & 110404 & DEPARTAMENTO DE ADMINISTRAÇÃO INTERNA & $22 / 11 / 2010$ \\
\hline$\underline{582010}$ & 110404 & DEPARTAMENTO DE ADMINISTRAÇÃO INTERNA & $24 / 11 / 2010$ \\
\hline$\underline{592010}$ & 110404 & DEPARTAMENTO DE ADMINISTRAÇÃO INTERNA & $29 / 11 / 2010$ \\
\hline$\underline{602010}$ & 110404 & DEPARTAMENTO DE ADMINISTRAÇÃO INTERNA & $06 / 12 / 2010$ \\
\hline$\underline{612010}$ & 110404 & DEPARTAMENTO DE ADMINISTRAÇÃO INTERNA & $09 / 12 / 2010$ \\
\hline$\underline{622010}$ & 110404 & DEPARTAMENTO DE ADMINISTRAÇÃO INTERNA & $09 / 12 / 2010$ \\
\hline$\underline{632010}$ & 110404 & DEPARTAMENTO DE ADMINISTRAÇÃO INTERNA & $13 / 12 / 2010$ \\
\hline$\underline{642010}$ & 110404 & DEPARTAMENTO DE ADMINISTRAÇÃO INTERNA & $14 / 12 / 2010$ \\
\hline$\underline{652010}$ & 110404 & DEPARTAMENTO DE ADMINISTRAÇÃO INTERNA & $15 / 12 / 2010$ \\
\hline$\underline{662010}$ & 110404 & DEPARTAMENTO DE ADMINISTRAÇÃO INTERNA & $07 / 01 / 2011$ \\
\hline$\underline{672010}$ & 110404 & DEPARTAMENTO DE ADMINISTRAÇÃO INTERNA & $16 / 12 / 2010$ \\
\hline$\underline{682010}$ & 110404 & DEPARTAMENTO DE ADMINISTRAÇÃO INTERNA & $09 / 02 / 2011$ \\
\hline$\underline{692010}$ & 110404 & DEPARTAMENTO DE ADMINISTRAÇÃO INTERNA & $20 / 12 / 2010$ \\
\hline$\underline{702010}$ & 110404 & DEPARTAMENTO DE ADMINISTRAÇÃO INTERNA & $23 / 12 / 2010$ \\
\hline$\underline{712010}$ & 110404 & DEPARTAMENTO DE ADMINISTRAÇÃO INTERNA & $29 / 12 / 2010$ \\
\hline$\underline{722010}$ & 110404 & DEPARTAMENTO DE ADMINISTRAÇÃO INTERNA & $30 / 12 / 2010$ \\
\hline$\underline{732010}$ & 110404 & DEPARTAMENTO DE ADMINISTRAÇÃO INTERNA & $30 / 12 / 2010$ \\
\hline
\end{tabular}




\title{
Presidência da República \\ Casa Civil \\ Subchefia para Assuntos Jurídicos
}

\author{
Regulamenta o Sistema de Registro \\ de Preços previsto no art. 15 da Lei \\ no 8.666 , de 21 de junho de 1993, e \\ dá outras providências.
}

O PRESIDENTE DA REPÚBLICA, no uso das atribuições que lhe confere o art. 84, incisos IV e VI, alínea "a", da Constituição, e nos termos do disposto no art. 15 da Lei $n \cong 8.666$, de 21 de junho de 1993 ,

\section{DECRETA:}

Art. 1 As contratações de serviços, a locação e a aquisição de bens quando efetuadas pelo Sistema de Registro de Preços, no âmbito da Administração Federal direta, autárquica e fundacional, fundos especiais, empresas públicas, sociedade de economia mista e demais entidades controladas, direta ou indiretamente pela União, obedecerão ao disposto neste Decreto.

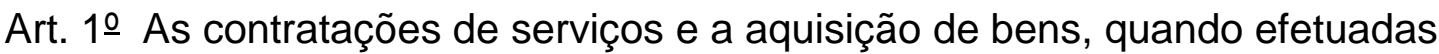
pelo Sistema de Registro de Preços, no âmbito da Administração Federal direta, autárquica e fundacional, fundos especiais, empresas públicas, sociedades de economia mista e demais entidades controladas, direta ou indiretamente pela União, obedecerão ao disposto neste Decreto.(Redação dada pelo Decreto $\mathrm{n}^{\circ}$ 4.342, de 23.8.2002)

Parágrafo único. Para os efeitos deste Decreto, são adotadas as seguintes definições:

L-Sistema de Registro de Preços - SRP - conjunto de procedimentos para registro formal de preços relativos à prestação de serviços, aquisição e locação de bens, para contratações futuras;

I - Sistema de Registro de Preços - SRP - conjunto de procedimentos para registro formal de preços relativos à prestação de serviços e aquisição de bens, para contratações futuras;(Redação dada pelo Decreto $n=4.342$, de 23.8.2002) 
II - Ata de Registro de Preços - documento vinculativo, obrigacional, com característica de compromisso para futura contratação, onde se registram os preços, fornecedores, órgãos participantes e condições a serem praticadas, conforme as disposições contidas no instrumento convocatório e propostas apresentadas;

III - Órgão Gerenciador - órgão ou entidade da Administração Pública responsável pela condução do conjunto de procedimentos do certame para registro de preços e gerenciamento da Ata de Registro de Preços dele decorrente; e

IV - Órgão Participante - órgão ou entidade que participa dos procedimentos iniciais do SRP e integra a Ata de Registro de Preços.

Art. 2으 Será adotado, preferencialmente, o SRP nas seguintes hipóteses:

I - quando, pelas características do bem ou serviço, houver necessidade de contratações freqüentes;

II - quando for mais conveniente a aquisição de bens com previsão de entregas parceladas ou contratação de serviços necessários à Administração para o desempenho de suas atribuições;

III - quando for conveniente a aquisição de bens ou a contratação de serviços para atendimento a mais de um órgão ou entidade, ou a programas de governo; e

IV - quando pela natureza do objeto não for possível definir previamente o quantitativo a ser demandado pela Administração.

Parágrafo único. Poderá ser realizado registro de preços para contratação de bens e serviços de informática, obedecida a legislação vigente, desde que devidamente justificada e caracterizada a vantagem econômica.

Art. 3 o A licitação para registro de preços será realizada na modalidade concorrência, do tipo menor preço, nos termos da Lei no 8.666, de 1993, e será precedida ampla pesquisa de mercado.

$\S 10$ Excepcionalmente poderá ser adotado o tipo técnica e preço, a critério do órgão gerenciador e mediante despacho devidamente fundamentado da autoridade máxima do órgão ou entidade.

Art. 3o A licitação para registro de preços será realizada na modalidade de concorrência ou de pregão, do tipo menor preço, nos termos das Leis nos 8.666, de 21 de julho de 1993, e 10.520, de 17 de julho de 2002, e será precedida de ampla pesquisa de mercado.(Redação dada pelo Decreto $n^{\circ}$ 4.342, de 23.8.2002) 
$\S 1$ 을 Excepcionalmente poderá ser adotado, na modalidade de concorrência, o tipo técnica e preço, a critério do órgão gerenciador e mediante despacho devidamente fundamentado da autoridade máxima do órgão ou entidade.(Redação dada pelo Decreto $\mathrm{n}^{\circ}$ 4.342, de 23.8.2002)

$\S 2$ 으 Caberá ao órgão gerenciador a prática de todos os atos de controle e administração do SRP, e ainda o seguinte:

I - convidar, mediante correspondência eletrônica ou outro meio eficaz, os órgãos e entidades para participarem do registro de preços;

II - consolidar todas as informações relativas à estimativa individual e total de consumo, promovendo a adequação dos respectivos projetos básicos encaminhados para atender aos requisitos de padronização e racionalização;

III - promover todos os atos necessários à instrução processual para a realização do procedimento licitatório pertinente, inclusive a documentação das justificativas nos casos em que a restrição à competição for admissível pela lei;

IV - realizar a necessária pesquisa de mercado com vistas à identificação dos valores a serem licitados;

V - confirmar junto aos órgãos participantes a sua concordância com o objeto a ser licitado, inclusive quanto aos quantitativos e projeto básico;

$\mathrm{VI}$-realizar todo o procedimento licitatório, bem como os atos dele decorrentes, tais como a assinatura da Ata e o encaminhamento de sua cópia aos demais órgãos participantes;

VII - gerenciar a Ata de Registro de Preços, providenciando a indicação, sempre que solicitado, dos fornecedores, para atendimento às necessidades da Administração, obedecendo a ordem de classificação e os quantitativos de contratação definidos pelos participantes da Ata;

VIII - conduzir os procedimentos relativos a eventuais renegociações dos preços registrados e a aplicação de penalidades por descumprimento do pactuado na Ata de Registro de Preços; e

IX - realizar, quando necessário, prévia reunião com licitantes, visando informá-los das peculiaridades do SRP e coordenar, com os órgãos participantes, a qualificação mínima dos respectivos gestores indicados.

§ 3 o O órgão participante do registro de preços será responsável pela manifestação de interesse em participar do registro de preços, providenciando o encaminhamento, ao órgão gerenciador, de sua estimativa de consumo, cronograma de contratação e respectivas especificações ou projeto básico, nos 
termos da Lei $\mathrm{n} \cong$ 8.666, de 1993, adequado ao registro de preço do qual pretende fazer parte, devendo ainda:

I - garantir que todos os atos inerentes ao procedimento para sua inclusão no registro de preços a ser realizado estejam devidamente formalizados e aprovados pela autoridade competente;

II - manifestar, junto ao órgão gerenciador, sua concordância com o objeto a ser licitado, antes da realização do procedimento licitatório; e

III - tomar conhecimento da Ata de Registros de Preços, inclusive as respectivas alterações porventura ocorridas, com o objetivo de assegurar, quando de seu uso, o correto cumprimento de suas disposições, logo após concluído o procedimento licitatório.

§ 4으 Cabe ao órgão participante indicar o gestor do contrato, ao qual, além das atribuições previstas no art. 67 da Lei no 8.666, de 1993, compete:

I-promover consulta prévia junto ao órgão gerenciador, quando da necessidade de contratação, a fim de obter a indicação do fornecedor, os respectivos quantitativos e os valores a serem praticados, encaminhando, posteriormente, as informações sobre a contratação efetivamente realizada;

II - assegurar-se, quando do uso da Ata de Registro de Preços, que a contratação a ser procedida atenda aos seus interesses, sobretudo quanto aos valores praticados, informando ao órgão gerenciador eventual desvantagem, quanto à sua utilização;

III - zelar, após receber a indicação do fornecedor, pelos demais atos relativos ao cumprimento, pelo mesmo, das obrigações contratualmente assumidas, e também, em coordenação com o órgão gerenciador, pela aplicação de eventuais penalidades decorrentes do descumprimento de cláusulas contratuais; e

IV - informar ao órgão gerenciador, quando de sua ocorrência, a recusa do fornecedor em atender às condições estabelecidas em edital, firmadas na Ata de Registro de Preços, as divergências relativas à entrega, as características e origem dos bens licitados e a recusa do mesmo em assinar contrato para fornecimento ou prestação de serviços.

Art. 4으 $\mathrm{O}$ prazo de validade da Ata de Registro de Preço não poderá ser superior a um ano, computadas neste as eventuais prorrogações. 
$\S 1$ Os contratos decorrentes do SRP terão sua vigência conforme as disposições contidas nos respectivos instrumentos convocatórios e respectivos contratos decorrentes, obedecido o disposto no art. 57 da Lei no 8.666, de 1993.

$\S 1$ o Os contratos decorrentes do SRP terão sua vigência conforme as disposições contidas nos instrumentos convocatórios e respectivos contratos, obedecido o disposto no art. 57 da Lei $n^{\circ}$ 8.666, de 1993.(Redação dada pelo Decreto $n^{\circ}$ 4.342, de 23.8.2002)

$\S 2$ 으 É admitida a prorrogação da vigência da Ata, nos termos do art. $57, \S$

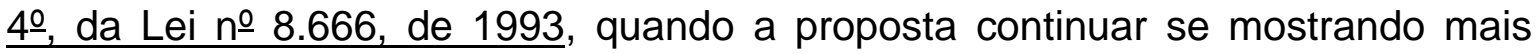
vantajosa, satisfeitos os demais requisitos desta norma.

Art. 5o A Administração, quando da aquisição de bens ou contratação de serviços, poderá subdividir a quantidade total do item em lotes, sempre que comprovado técnica e economicamente viável, de forma a possibilitar maior competitividade, observado, neste caso, dentre outros, a quantidade mínima, o prazo e o local de entrega ou de prestação dos serviços.

Parágrafo único. No caso de serviços, a subdivisão se dará em função da unidade de medida adotada para aferição dos produtos e resultados esperados, e será observada a demanda específica de cada órgão ou entidade participante do certame. Nestes casos, deverá ser evitada a contratação, num mesmo órgão e entidade, de mais de uma empresa para a execução de um mesmo serviço em uma mesma localidade, com vistas a assegurar a responsabilidade contratual e o princípio da padronização.

Art. 6으 Ao preço do primeiro colocado poderão ser registrados tantos fornecedores quantos necessários para que, em função das propostas apresentadas, seja atingida a quantidade total estimada para o item ou lote, observando-se o seguinte:

I - o preço registrado e a indicação dos respectivos fornecedores serão divulgados em órgão oficial da Administração e ficarão disponibilizados durante a vigência da Ata de Registro de Preços;

II - quando das contratações decorrentes do registro de preços deverá ser respeitada a ordem de classificação das empresas constantes da Ata; e

III - os órgãos participantes do registro de preços deverão, quando da necessidade de contratação, recorrerem ao órgão gerenciador da Ata de Registro de Preços, para que este proceda a indicação do fornecedor e respectivos preços a serem praticados. 
Parágrafo único. Excepcionalmente, a critério do órgão gerenciador, quando a quantidade do primeiro colocado não for suficiente para as demandas estimadas, desde que se trate de objetos de qualidade ou desempenho superior, devidamente justificada e comprovada a vantagem, e as ofertas sejam em valor inferior ao máximo admitido, poderão ser registrados outros preços.

Art. 7o $\mathrm{A}$ existência de preços registrados não obriga a Administração a firmar as contratações que deles poderão advir, facultando-se a realização de licitação específica para a aquisição pretendida, sendo assegurado ao beneficiário do registro a preferência de fornecimento em igualdade de condições.

Art. 8o A Ata de Registro de Preços, durante sua vigência, poderá ser utilizada por qualquer órgão ou entidade da Administração que não tenha participado do certame licitatório, mediante prévia consulta ao órgão gerenciador, desde que devidamente comprovada a vantagem.

$\S 1$ o Os órgãos e entidades que não participaram do registro de preços, quando desejarem fazer uso da Ata de Registro de Preços, deverão manifestar seu interesse junto ao órgão gerenciador da Ata, para que este indique os possíveis fornecedores e respectivos preços a serem praticados, obedecida a ordem de classificação.

§ 2으 Caberá ao fornecedor beneficiário da Ata de Registro de Preços, observadas as condições nela estabelecidas, optar pela aceitação ou não do fornecimento, independentemente dos quantitativos registrados em Ata, desde que este fornecimento não prejudique as obrigações anteriormente assumidas.

$\S 3^{\circ}$ As aquisições ou contratações adicionais a que se refere este artigo não poderão exceder, por órgão ou entidade, a cem por cento dos quantitativos registrados na Ata de Registro de Preços. (Incluído pelo Decreto no 4.342, de 23.8.2002)

Art. go O edital de Concorrência para Registro de Preços contemplará, pelo menos:

Art. 9o $\mathrm{O}$ edital de licitação para registro de preços contemplará, no mínimo: (Redação dada pelo Decreto no 4.342 , de 23.8.2002)

I - a especificação/descrição do objeto, explicitando o conjunto de elementos necessários e suficientes, com nível de precisão adequado, para a caracterização do bem ou serviço, inclusive definindo as respectivas unidades de medida usualmente adotadas; 
II - a estimativa de quantidades a serem adquiridas no prazo de validade do registro;

III - o preço unitário máximo que a Administração se dispõe a pagar, por contratação, consideradas as regiões e as estimativas de quantidades a serem adquiridas;

IV - a quantidade mínima de unidades a ser cotada, por item, no caso de bens;

$\mathrm{V}$ - as condições quanto aos locais, prazos de entrega, forma de pagamento e, complementarmente, nos casos de serviços, quando cabíveis, a freqüência, periodicidade, características do pessoal, materiais e equipamentos a serem fornecidos e utilizados, procedimentos a serem seguidos, cuidados, deveres, disciplina e controles a serem adotados;

VI - o prazo de validade do registro de preço;

VII - os órgãos e entidades participantes do respectivo registro de preço;

VIII - os modelos de planilhas de custo, quando cabíveis, e as respectivas minutas de contratos, no caso de prestação de serviços; e

IX - as penalidades a serem aplicadas por descumprimento das condições estabelecidas.

$\S 1$ @ $\bigcirc$ edital poderá admitir, como critério de adjudicação, a oferta de desconto sobre tabela de preços praticados no mercado, nos casos de peças de veículos, medicamentos, passagens aéreas, manutenções e outros similares.

§ 2o Quando o edital prever o fornecimento de bens ou prestação de serviços em locais diferentes, é facultada a exigência de apresentação de proposta diferenciada por região, de modo que aos preços sejam acrescidos os respectivos custos, variáveis por região.

Art. 10. Homologado o resultado da licitação, o órgão gerenciador, respeitada a ordem de classificação e a quantidade de fornecedores a serem registrados, convocará os interessados para assinatura da Ata de Registro de Preços que, após cumpridos os requisitos de publicidade, terá efeito de compromisso de fornecimento nas condições estabelecidas.

Art. 11. A contratação com os fornecedores registrados, após a indicação pelo órgão gerenciador do registro de preços, será formalizada pelo órgão interessado, por intermédio de instrumento contratual, emissão de nota de empenho de despesa, autorização de compra ou outro instrumento similar, conforme o disposto no art. 62 da Lei no 8.666, de 1993. 
Art. 12. A Ata de Registro de Preços poderá sofrer alterações, obedecidas as disposições contidas no art. 65 da Lei no 8.666, de 1993.

$\S 1$ o O preço registrado poderá ser revisto em decorrência de eventual redução daqueles praticados no mercado, ou de fato que eleve o custo dos serviços ou bens registrados, cabendo ao órgão gerenciador da Ata promover as necessárias negociações junto aos fornecedores.

$\S$ 2oㅡ Quando o preço inicialmente registrado, por motivo superveniente, tornar-se superior ao preço praticado no mercado o órgão gerenciador deverá:

I - convocar o fornecedor visando a negociação para redução de preços e sua adequação ao praticado pelo mercado;

II - frustrada a negociação, o fornecedor será liberado do compromisso assumido; e

III - convocar os demais fornecedores visando igual oportunidade de negociação.

$\S 3$ ㅇ Quando o preço de mercado tornar-se superior aos preços registrados e o fornecedor, mediante requerimento devidamente comprovado, não puder cumprir o compromisso, o órgão gerenciador poderá:

I - liberar o fornecedor do compromisso assumido, sem aplicação da penalidade, confirmando a veracidade dos motivos e comprovantes apresentados, e se a comunicação ocorrer antes do pedido de fornecimento; e

II-convocar os demais fornecedores visando igual oportunidade de negociação.

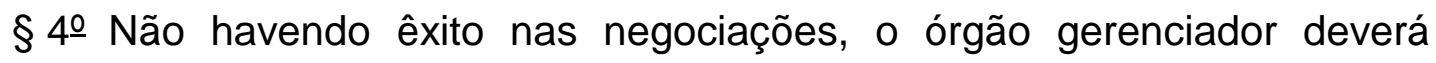
proceder à revogação da Ata de Registro de Preços, adotando as medidas cabíveis para obtenção da contratação mais vantajosa.

Art. 13. O fornecedor terá seu registro cancelado quando:

I - descumprir as condições da Ata de Registro de Preços;

II - não retirar a respectiva nota de empenho ou instrumento equivalente, no prazo estabelecido pela Administração, sem justificativa aceitável;

III - não aceitar reduzir o seu preço registrado, na hipótese de este se tornar superior àqueles praticados no mercado; $\mathrm{e}$

IV - tiver presentes razões de interesse público.

$\S 1$ o O cancelamento de registro, nas hipóteses previstas, assegurados 0 contraditório e a ampla defesa, será formalizado por despacho da autoridade competente do órgão gerenciador. 
$\S$ 2oㅡ O fornecedor poderá solicitar o cancelamento do seu registro de preço na ocorrência de fato superveniente que venha comprometer a perfeita execução contratual, decorrentes de caso fortuito ou de força maior devidamente comprovados.

Art. 14. Poderá ser utilizado recursos de tecnologia da informação nos procedimentos e atribuições de que trata este Decreto, na forma prevista em regulamentação específica.

Art. 14. Poderão ser utilizados recursos de tecnologia da informação na operacionalização das disposições de que trata este Decreto, bem assim na automatização dos procedimentos inerentes aos controles e atribuições dos órgãos gerenciador e participante.(Redação dada pelo Decreto no 4.342, de $\underline{23.8 .2002)}$

Art. 15. O Ministério do Planejamento, Orçamento e Gestão poderá editar normas complementares a este Decreto.

Art. 16. Este Decreto entra em vigor na data de sua publicação.

Art. 17. Revoga-se o Decreto $\mathrm{n}=2.743$, de 21 de agosto de 1998. Brasília, 19 de setembro de 2001; 180으 da Independência e 113으 da República. FERNANDO HENRIQUE CARDOSO

\section{Martus Tavares}

Este texto não substitui o publicado no D.O.U. 20.9.2001 